\title{
Water quality of Flag Boshielo Dam, Olifants River, South Africa: Historical trends and the impact of drought
}

\author{
J Dabrowski ${ }^{1,2 *}$, PJ Oberholster ${ }^{1,3}$ and JM Dabrowski \\ 'Department of Paraclinical Sciences, Faculty of Veterinary Science, University of Pretoria, P/Bag X04, Onderstepoort 0110, South Africa \\ ${ }^{2}$ CSIR Natural Resources and the Environment, PO Box 395, Pretoria, 0001, South Africa \\ ${ }^{3}$ CSIR Natural Resources and the Environment, PO Box 320, Stellenbosch, 7599, South Africa
}

\begin{abstract}
Increasing demands for water, discharge of effluents, and variable rainfall have a negative impact on water quality in the Olifants River. Crocodile and fish mortalities attributed to pansteatitis, in Loskop Dam and downstream in the Kruger National Park (KNP), have highlighted the serious effects these impacts are having on aquatic ecosystems. Flag Boshielo Dam is a reservoir on the Olifants River, located between Loskop Dam and the KNP. It has the largest crocodile population outside of the KNP, and pansteatitis has not been reported in fish or crocodiles to date. This study evaluated comparative water quality parameters concurrent to a similar study undertaken at Loskop Dam to establish possible environmental drivers of pansteatitis. Long-term monitoring data collected by the Department of Water Affairs were analysed for trends using a Seasonal-Kendall trend test. Short-term monitoring showed that water quality in Flag Boshielo Dam was of a good standard for ecosystem health. Concentrations of dissolved $\mathrm{Cu}, \mathrm{Se}, \mathrm{V}$ and $\mathrm{Zn}$ were always below instrument detection limits, and $\mathrm{Al}, \mathrm{Fe}$ and $\mathrm{Mn}$ were mostly within guideline levels for ecosystem health. A severe drought occurred between November 2002 and December 2005. Long-term monitoring showed that water quality during the drought deteriorated, with high levels of dissolved salts, especially $\mathrm{K}, \mathrm{Na}, \mathrm{Cl}, \mathrm{F}$, and total alkalinity. Following the drought, dissolved salt concentrations dropped, and there was a brief flush of inorganic N and P. However, between 1998 and 2011, inorganic N showed a significant decreasing trend into the oligotrophic range, while inorganic $\mathrm{P}$ remained in the oligo- to mesotrophic range. The inorganic $\mathrm{N}$ to inorganic $\mathrm{P}$ ratio of 5.4 after the drought was indicative of $\mathrm{N}$ limitation, and the phytoplankton assemblage was dominated by nitrogen-fixing species, especially Cylindrospermopsis sp. In contrast, further upstream, Loskop Dam has undergone increasing eutrophication, has frequent blooms of Microcystis aeruginosa and Ceratium hirundinella, and concentrations of Al, Fe and $\mathrm{Mn}$ periodically exceed guideline levels. The difference in trophic state, phytoplankton assemblage and levels of productivity between these two reservoirs may provide insights into the aetiology of pansteatitis, which is frequently associated with dietary causes.
\end{abstract}

Keywords: Flag Boshielo Dam, limnology, Olifants River, trend analysis, drought, nitrogen limitation

\section{INTRODUCTION}

Flag Boshielo Dam was built in 1987 for irrigation of agriculture downstream of the dam, to supply municipal water to the town of Polokwane, and to ensure dry-season water storage for mines in the area (Van Koppen, 2008). It is located at the confluence of the Olifants and Elands rivers, approximately 30 $\mathrm{km}$ from the town of Marble Hall in the Limpopo Province. In March 2006, the dam wall was raised by $5 \mathrm{~m}$ in order to secure water for mining development, and to improve supply to rural communities through the Olifants River Water Resource Development Programme (Van Koppen, 2008). The raising of the dam wall coincided with the end of a drought that lasted approximately 3 years, which provided additional motivation to increase the reservoir capacity. The drought ended in January 2006 with the first significant flows into the reservoir occurring 2 months prior to completion of construction on the dam wall.

Wide-scale irrigated agriculture along the Olifants River is the predominant catchment land use downstream of Loskop Dam, while dryland and irrigated agriculture occur in the

\footnotetext{
To whom all correspondence should be addressed.

Iili +27 83 2563159; fax: +27 128413954 ;

e-mail: jdabrowski1@csir.co.za

Received 24 July 2013; accepted in revised form 3 March 2014.
}

Elands River catchment. Upstream of Flag Boshielo Dam, Loskop Dam supplies water to the Loskop Irrigation Board, the second largest in South Africa. The irrigation board supplies 700 properties which cover an area of 16117 ha within the Flag Boshielo Dam catchment (Oberholster and Botha, 2011). Major crops include cotton, wheat, citrus and grapes, a significant proportion of which are grown for export. In contrast to Loskop Dam, there is very little mining and industry in the catchment, although its location downstream from Loskop Dam means that Flag Boshielo Dam is susceptible to the same impacts affecting water quality in the upper catchment. Subsistence farming in the catchment has led to land degradation with extensive areas of soil erosion, and subsequent elevated suspended sediment loads in waterways. Inadequate water supply, sanitation and waste disposal systems place additional pressure on the water resources in the area (Moolman et al., 1999; Magagula et al., 2006). Not all wastewater treatment works (WWTW) in the catchment function optimally, which can result in high inputs of phosphorus-enriched effluent discharged into receiving water bodies. In particular, the Marble Hall WWTW, which discharges into the Elands River, was categorised as being in a critical state at the time of this study, scoring only 23.4\% in the 2011 Green Drop report (DWA, 2011).

Recent water quality concerns upstream in Loskop Dam include eutrophication, Microcystis blooms, acid mine drainage related impacts, and the as yet unexplained occurrence of 
the disease, pansteatitis, in crocodiles (Crocodylus niloticus) and Mozambique tilapia (Oreochromis mossambicus) (Ashton, 2010; Oberholster et al., 2010). To date, none of these issues have been reported in Flag Boshielo Dam. Pansteatitis has also been reported further downstream in the Olifants River in the Kruger National Park (KNP), where over 180 pansteatitisaffected crocodiles died (Huchzermeyer et al., 2011), and the population is in decline (Ferreira and Pienaar, 2011). The condition has also been described in sharptooth catfish (Clarias gariepinus) at this location (Huchzermeyer et al., 2011). With around 135 individuals, Flag Boshielo Dam has the highest concentration of Nile crocodiles in the Olifants River system, outside of the KNP. Their number has reportedly decreased by $27 \%$ since 2005 , before the dam wall was raised. However this decrease was attributed to habitat loss, as opposed to water quality concerns or pansteatitis (Botha, 2010).

The occurrence of pansteatitis in two geographically distinct aquatic animal populations on the same river is remarkable. Flag Boshielo Dam is conspicuous by the absence of pansteatitis in fish and crocodiles, despite being located downstream of Loskop Dam. This makes it a suitable negative control site for research into the aetiology of the disease. During a study of the health of O. mossambicus from Loskop Dam, historic trends and selected water quality parameters were evaluated in an effort to determine the environmental drivers that may be involved in the aetiology of pansteatitis (Dabrowski et al., 2013). The study focussed on parameters influenced by dominant catchment land uses such as the trophic state and metal concentrations. The primary objective of this study was to provide comparative information on the same parameters, and the limnology and water chemistry of Flag Boshielo Dam. While the two reservoirs are certain to have inherent differences related to factors such as their physiography, differences in physico-chemical dynamics related to various anthropogenic impacts may provide insights into the causes of pansteatitis. In addition, long-term monitoring data collected by the Department of Water Affairs (DWA) were analysed for trends to provide a more comprehensive assessment of water quality. This assessment included a multivariate analysis of water quality characteristics associated with the drought between 2002 and 2006.

\section{METHODS}

\section{Study site}

Flag Boshielo Dam ( $24^{0} 46^{\prime} 50^{\prime \prime}$ S; $29^{\circ} 25^{\prime} 32^{\prime \prime}$ E) is located near the town of Marble Hall in Limpopo Province, South Africa. Four water quality monitoring sites were selected for this study. At the inflow of the Olifants River (FB0), the confluence with the Elands River in the dam (FB1), after the confluence with the Elands River (FB2), and in the main basin near the dam wall (FB3). The Department of Water Affairs (DWA) water quality monitoring station (B5R002) is also located near the dam wall (Fig. 1). When full supply level (FSL) is exceeded water flows over a spillway. There is a continuous outflow of water via a pipeline for drinking water purposes, and downstream flow in the Olifants River is augmented as required by water released for irrigation, mining and domestic use. Vegetation in the catchment consists predominantly of mixed Thornveld and Bushveld, much of which has been degraded, with a small proportion of Highveld Grassland in the upper catchment of the Elands River (Mucina and Rutherford, 2006). The catchment is underlain by intrusive igneous rocks (granite and gneiss) of

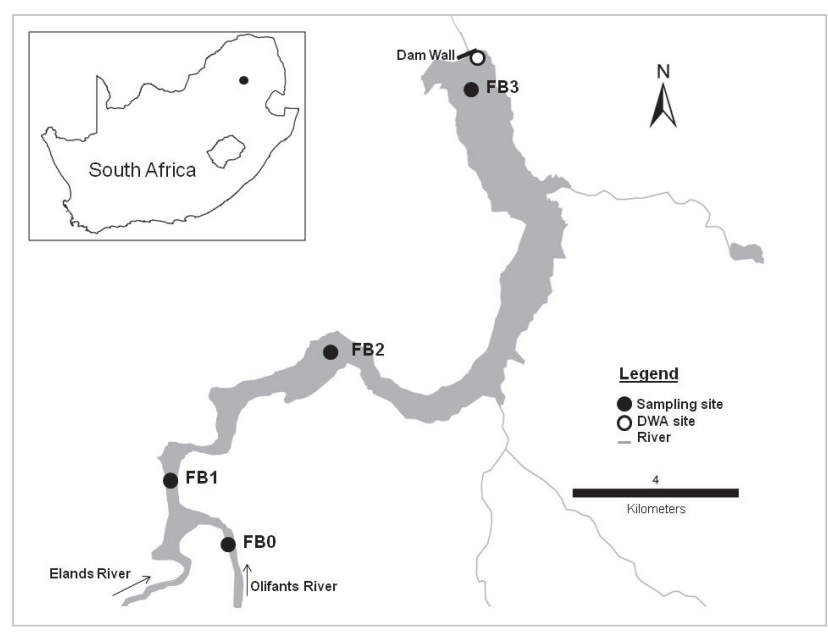

Figure 1

Map of Flag Boshielo Dam showing the location of 4 sampling sites monitored during 2011, and the Department of Water Affairs (DWA) monitoring site

the Lebowa Granite Suite (LGS), which are part of the Bushveld Igneous Complex (Johnson et al., 2006).

\section{Reservoir physiography}

Mean annual runoff was calculated from the sum of annual flows recorded at DWA gauging stations B3H001 (Loskop North) and B3H021 (Scherp Arabie). Only complete annual records (12 months) monitored simultaneously at both stations were included in the calculation. This limited the dataset to 17 of the years between 1990 and 2009. The mean retention time was estimated by dividing the mean annual runoff by the reservoir volume (Dodds and Whiles, 2010), and the mean depth was calculated by dividing reservoir volume by reservoir area (Timms, 2010). Shoreline length was obtained from the DWA Directorate of Spatial and Land Information Management. All other values in Table 1 were obtained from the DWA station catalogue (DWA, 2013). Shoreline development $\left(D_{L}\right)$ is an index that quantifies the irregularity of the shore. A perfect circle would have a $D_{L}$ value of 1 , with larger values indicating that the shoreline is more convoluted. The index was calculated as follows:

$$
\begin{aligned}
& \quad \mathrm{D}_{\mathrm{L}}=\frac{L}{2 \sqrt{\pi A_{0}}} \\
& \text { where: } \\
& \quad L \text { is shoreline length }(\mathrm{km}) \\
& A_{0} \text { is reservoir surface area }\left(\mathrm{km}^{2}\right)
\end{aligned}
$$

Reservoirs with high shoreline development are often naturally more productive than those with low shoreline development (Dodds and Whiles, 2010).

\section{Physico-chemical characteristics}

Each of the sites in Flag Boshielo Dam was sampled on 5 occasions during February, April, June, October and December 2011 , to cover seasonal variation in an annual cycle. One-litre integrated $(2 \mathrm{~m})$ water samples were collected using a plastic hose (diameter $5 \mathrm{~cm}$ ) lowered vertically into the water and then emptied into a plastic bucket and mixed prior to collecting the sample with a plastic container rinsed in water from the sampling site. Samples were refrigerated at $4^{\circ} \mathrm{C}$ in the field and 
then frozen until they were delivered to the accredited CSIR Analytical Laboratory in Stellenbosch. Samples were filtered through $0.45 \mu \mathrm{m}$ pore size Whatman GF filters prior to being analysed for dissolved nutrients, metals and major ions using standard methods (APHA, 1998). Acid soluble concentrations of aluminium (Al), iron ( $\mathrm{Fe})$, manganese $(\mathrm{Mn})$, selenium (Se), vanadium $(\mathrm{V})$, zinc $(\mathrm{Zn})$ and copper $(\mathrm{Cu})$ were determined using inductively coupled plasma mass spectrometry (ICP-MS). Acid soluble concentrations of all major ions except chloride $(\mathrm{Cl})$ and fluoride $(\mathrm{F})$ were analysed using inductively coupled plasma optical emission spectrometry (ICP-OES). Chloride, and dissolved reactive nitrogen $(\mathrm{N})$ and phosphorus $(\mathrm{P})$ were measured using a flow injection analyser (FIA). Fluoride was measured using ion-selective electrode analysis. A 1- $\ell$ subsample of water was collected from the bucket and stored at $4^{\circ} \mathrm{C}$, covered in foil, for analysis of chlorophyll- $a$ concentrations. Samples were filtered using Whatman GF filters and then lyophilised. Chlorophyll- $a$ was extracted using N,Ndimethylformamide for $2 \mathrm{~h}$ at room temperature, then measured spectrophotometrically at $647 \mathrm{~nm}$ and $664 \mathrm{~nm}$ (Porra et al., 1989).

Field measurements of $\mathrm{pH}$, dissolved oxygen, conductivity, and temperature of the surface water were taken along with water transparency using a Secchi disc $(25 \mathrm{~cm})$ at each site. Measurements were made using a Hach HQ40D multiparameter meter using a $\mathrm{pH}$ gel intellical probe, luminescent dissolved oxygen intellical probe and a standard 4-pole graphite type electrical conductivity intellical probe (USEPA compliant). Vertical profiles of $\mathrm{pH}$, dissolved oxygen and temperature were measured to a maximum depth of $30 \mathrm{~m}$ using the same meter at Site FB3 during each sampling period.

Censored values were replaced at 0.55 of the detection limit. All values were compared to guidelines for aquatic ecosystem health where provided (DWAF, 1996a). The guidelines provide a management objective known as the target water quality range (TWQR). This is the concentration at which no adverse effects on the health of aquatic ecosystems are expected. The sulphate $\left(\mathrm{SO}_{4}^{2-}\right)$ to $\mathrm{Cl}^{-}$ratio was calculated as an indicator of mining and industrial contributions to changes in water quality. It is calculated from the ionic activity as $\mathrm{SO}_{4}^{2-} / \mathrm{Cl}^{-}$. A value greater than 5.0 indicates that these land uses are having an adverse impact on water quality (Ashton and Dabrowski, 2011).

\section{Drought characterisation}

The Standardised Precipitation Index (SPI) developed by McKee et al. (1993) is widely recommended as the preferred index to characterise meteorological droughts (Svoboda et al., 2012). The SPI fits data to a gamma probability distribution, which is then transformed to a normal distribution so that the mean SPI for a location and time period is zero (Edwards and MKee, 1997). The index can be used to monitor both wet and dry events. A drought event occurs when the SPI first falls below zero, and ends when the SPI becomes positive (Svoboda et al., 2012). Drought intensity is defined by the following categories: 0 to $-0.99=$ mild drought; -1.00 to $-1.49=$ moderate drought; 1.50 to $-1.99=$ severe drought $; \leq-2.00=$ extreme drought (McKee et al., 1993). The 12-month SPI was calculated as it represents a long-term timescale and is usually tied to streamflows and reservoir levels (Svoboda et al., 2012). Monthly rainfall (mm) records from 1952 until 2011 (59 years) were obtained for 3 stations in the catchment of Flag Boshielo Dam (Loskop Irrigation Board; Aquaville; Marble Hall), from the South African Weather Service (SAWS). The SPI was calculated using an open source SPI program (SPI_SL_6.exe) recommended by the World Meteorological Organisation, and downloaded from http://drought.unl.edu/MonitoringTools/ DownloadableSPIProgram.aspx.

\section{Department of Water Affairs monitoring data}

\section{Data reliability}

The data record collected during routine water quality monitoring by DWA had several shortcomings which were addressed as follows, prior to analysis using standard methods (APHA, 1998; Ashton and Dabrowski, 2011). Where duplicate samples were recorded on several dates, only surface water samples were retained; the first complete set of analyses for a particular date was selected, and the rest of the data were discarded. The ionic activity balance was calculated for each sample using available cations $\mathrm{Ca}^{2+}, \mathrm{Mg}^{2+}, \mathrm{Na}^{+}, \mathrm{K}^{+}$, and ammonium- $\mathrm{N}\left(\mathrm{NH}_{4}^{+}\right)$, and anions $\mathrm{Cl}^{-}, \mathrm{SO}_{4}^{2-}$, carbonate $\left(\mathrm{CO}_{3}^{2-}\right.$, calculated from total alkalinity), nitrate $\left(\mathrm{NO}_{3}{ }^{-}\right)$and $\mathrm{F}$. Where the difference between the cation charge and anion charge was greater than $5 \%$ of the ionic charge, samples were excluded from the analyses (APHA, 1998). A total of 37 samples (12.3\%) were unreliable and subsequently rejected.

Between 2009 and $2011 \mathrm{~F}$ was not measured in several samples. However, samples that balanced were retained, despite the exclusion of F, as it is not considered to be a major constituent of total dissolved salts (Wetzel, 1983). Sampling frequency varied from monthly to weekly, so data were aggregated to single monthly values using the median of the available data. Multiple detection limits were common so censored data were recensored to the highest detection limit in the data range (Helsel and Hirsch, 2002).

\section{Trophic status}

The trophic status and eutrophication potential of Flag Boshielo Dam was calculated using chlorophyll- $a$ and total P concentrations measured between 2005 and 2011. Classification was determined according to the National Eutrophication Monitoring Programme (DWAF, 2002). Phytoplankton samples collected by DWA during the same time period were evaluated in order to compare the dominant species in Flag Boshielo Dam to those upstream in Loskop Dam.

\section{Trend analyses}

Data were tested for trends using a nonparametric procedure performed in XLSTAT version 2012.6.08 Addinsoft. The Seasonal-Kendall test was used to detect monotonic trends in the data, which are continuous changes in a variable over time (Hirsch et al., 1982). The null hypothesis of this test is that a random variable is independent of time. The Seasonal-Kendall test accounted for seasonal variation by computing statistics for each season (each month in this study), summing the test statistics, and evaluating the overall summed statistic (Hirsch et al., 1982).

Dam level (m) had a considerable influence on several parameters, and was therefore included in the Seasonal-Kendall test as an exogenous variable. This was accomplished by modelling the relationship between dam level and each $Y$ variable using the LOWESS smoothing technique with a smoothing parameter (span) of 0.5 , which does not assume linearity or normality of residuals (Helsel and Hirsch, 2002). The residuals 


\section{TABLE 1}

Attributes of Flag Boshielo Dam at full supply level before and after the dam wall was raised by $5 \mathrm{~m}$ in March 2006, including relevant catchment attributes

\begin{tabular}{|l|c|c|}
\hline Catchment attributes & $\begin{array}{c}\text { Pre-March } \\
\mathbf{2 0 0 6}\end{array}$ & $\begin{array}{c}\text { Post-March } \\
\mathbf{2 0 0 6}\end{array}$ \\
\hline $\begin{array}{l}\text { Elands River mean annual flow } \\
\left(\mathrm{x} 10^{6} \mathrm{~m}^{3}\right)\end{array}$ & NA & 28.51 \\
\hline $\begin{array}{l}\text { Olifants River mean annual flow } \\
\left(\mathrm{x} 10^{6} \mathrm{~m}^{3}\right)\end{array}$ & NA & 218.45 \\
\hline Mean annual runoff $\left(\mathrm{x} 10^{6} \mathrm{~m}^{3}\right)$ & NA & 382.89 \\
\hline Catchment area $\left(\mathrm{km}^{2}\right)$ & NA & 23,555 \\
\hline Reservoir attributes & 35 & 40 \\
\hline Dam wall height AC $(\mathrm{m})$ & 28 & 33 \\
\hline Maximum Depth AC $(\mathrm{m})$ & 7.69 & 8.6 \\
\hline Mean Depth $(\mathrm{m})$ & 98.99 & 188.85 \\
\hline Volume $\left(\mathrm{x} 10^{6} \mathrm{~m}^{3}\right)$ & 12.87 & 21.9 \\
\hline Surface area $\left(\mathrm{km}^{2}\right)$ & 3.9 & 4.9 \\
\hline Mean retention time $(\mathrm{months})$ & 817 & 822.09 \\
\hline Elevation above sea level $(\mathrm{m})$ & $\mathrm{ND}$ & 82.1 \\
\hline Shoreline length ${ }^{\star}(\mathrm{km}, \mathrm{scale} 1: 5000)$ & $\mathrm{ND}$ & 4.94 \\
\hline Shoreline development $\left(\mathrm{D}_{\mathrm{I}}\right)$ & & \\
\hline
\end{tabular}

NA, Not Applicable; ND, Not Determined; ${ }^{*}$ scale 1:5000, shoreline contour $823 \mathrm{~m}$

were then analysed, thereby removing the effect of dam level and allowing any trends to be more clearly observed. Trends for each parameter were only calculated if less than $50 \%$ of the data were censored and more than 5 years of data were available (Stevens, 2003).

\section{Principal component analysis}

With no a priori presumptions of data relationships, a principal component analysis (PCA) was used to detect groupings in the water samples collected by the DWA. Twelve water quality parameters were analysed including $\mathrm{pH}$, major ions, dissolved nutrients and silica concentrations. Samples were grouped according to normal flows or drought periods as determined by the SPI and examining inflow data from the Olifants River and Elands River, along with water levels in Flag Boshielo Dam. The analysis was completed in Statistica Version 11 (StatSoft. Inc, Tulsa, USA).

\section{RESULTS}

\section{Reservoir physiography}

The mean annual flow from the Olifants River was almost 8 times greater than that from the Elands River (Table 1). An extensive area $\left(9.03 \mathrm{~km}^{2}\right)$ surrounding Flag Boshielo Dam was flooded when the dam wall was raised in March 2006, and vegetation was purposely not cleared from this area beforehand in order to provide habitat in the form of dead trees for waterfowl. As a result, submerged dead trees are scattered throughout most of the littoral zone. After the dam wall was raised, the mean depth increased, the volume and surface area almost doubled, and the mean retention time increased to 4.9 months (Table 1). The shoreline development value of 4.94 is greater than 3, which means that Flag Boshielo Dam has a highly irregular, dendritic or tree-shaped shoreline (Timms, 2010).

\section{Physico-chemical characteristics}

\section{Surface water chemistry}

A summary of selected water quality constituents measured during 2011 is presented in Table 2. Water in Flag Boshielo Dam was alkaline, with $\mathrm{pH}$ ranging from 7.38 to 9.42 , and relatively high total alkalinity (as $\mathrm{CaCO}_{3}$ ) ranging from $40 \mathrm{mg} / \ell$ to $87 \mathrm{mg} / \ell$. Dissolved oxygen was also consistently high with a median of $10.02 \mathrm{mg} / \ell$ (Table 2). While some spatial patterns in water quality constituents across the dam were evident, these were not very distinct, and seasonal patterns at sites were more apparent.

Sulphate concentrations were relatively constant across the dam, with an overall median of $92.5 \mathrm{mg} / \ell$ (Table 2), and while concentrations showed limited seasonal variation, the lowest values were observed in October (Fig. 2a). The sulphate:chloride ratio ranged widely from 2 to 7 with a median value of 4 , and all sites showed similar seasonal patterns. Values were higher in February, April and June, than in October and December (Fig. 2b) which was as a result of elevated $\mathrm{Cl}$ concentrations in the latter months (Fig. 2c). Both $\mathrm{Na}$ and $\mathrm{Cl}$ showed distinct and similar seasonal variation, with the lowest medians observed in February steadily increasing throughout the year to peak in December (Fig. 2c and d).

Concentrations of dissolved $\mathrm{Cu}, \mathrm{Se}, \mathrm{V}$ and $\mathrm{Zn}$ were never above instrument detection limits and were thus excluded from Table 2. Manganese concentrations were consistently within the TWQR throughout the study. The TWQR guideline for Fe stipulates that values should not vary by more than $10 \%$ from the background concentrations. Several values were censored during monitoring, making it impossible to determine a background concentration. However, when values were detected, they were relatively low and did not show substantial variation (Table 2). Dissolved Al concentrations exceeded the TWQR of $10 \mu \mathrm{g} / \ell$ in October and December at Sites FB0 and FB1, and at Site FB3 in December. The highest concentration of 14.9 $\mu \mathrm{g} / \ell$ was still well below the chronic effect value of $20 \mu \mathrm{g} / \ell$. In February, April and June, the detection limit was $20 \mu \mathrm{g} / \ell$, and no $\mathrm{Al}$ was detected above this limit.

Seasonal patterns in inorganic $\mathrm{N}$ showed a generally inverse relationship to chlorophyll- $a$ concentrations (Fig. 2e and g). The highest values were observed in February with a median value of $0.23 \mathrm{mg} / \ell$, which decreased in April and June, and was below detection limits at all sites in October and December. No inorganic N was detected at Sites FB2 and FB3 at any time during the study period, and detected levels at Sites FB0 and FB1 never exceeded $0.5 \mathrm{mg} / \ell$ (Table 2), which categorises Flag Boshielo Dam as oligotrophic (DWAF, 1996a). The inorganic P concentrations were also frequently censored, particularly during October and December when no inorganic $\mathrm{P}$ was detected at any sites (Table 2). During February, April and June, the values ranged from 0.01 to $0.084 \mathrm{mg} / \ell$ (Fig. 2f) which fall into the meso- to eutrophic category (DWAF, 1996a).

Inorganic $\mathrm{N}$ and $\mathrm{P}$ concentrations were frequently below the detection limit, which prevented the calculation of ratios for most sampling periods. Ratios were calculated when $\mathrm{N}$ and $\mathrm{P}$ were above detection limits, but not when both values were censored. The resulting ratios fluctuated widely, ranging from < 1 up to 72 (Table 2).

The reservoir was relatively turbid throughout monitoring. Secchi disk transparency was consistently low, with a median of $0.62 \mathrm{~m}$ and very limited spatial variation across the dam (Fig. 2h), although there was an apparent inverse relationship 

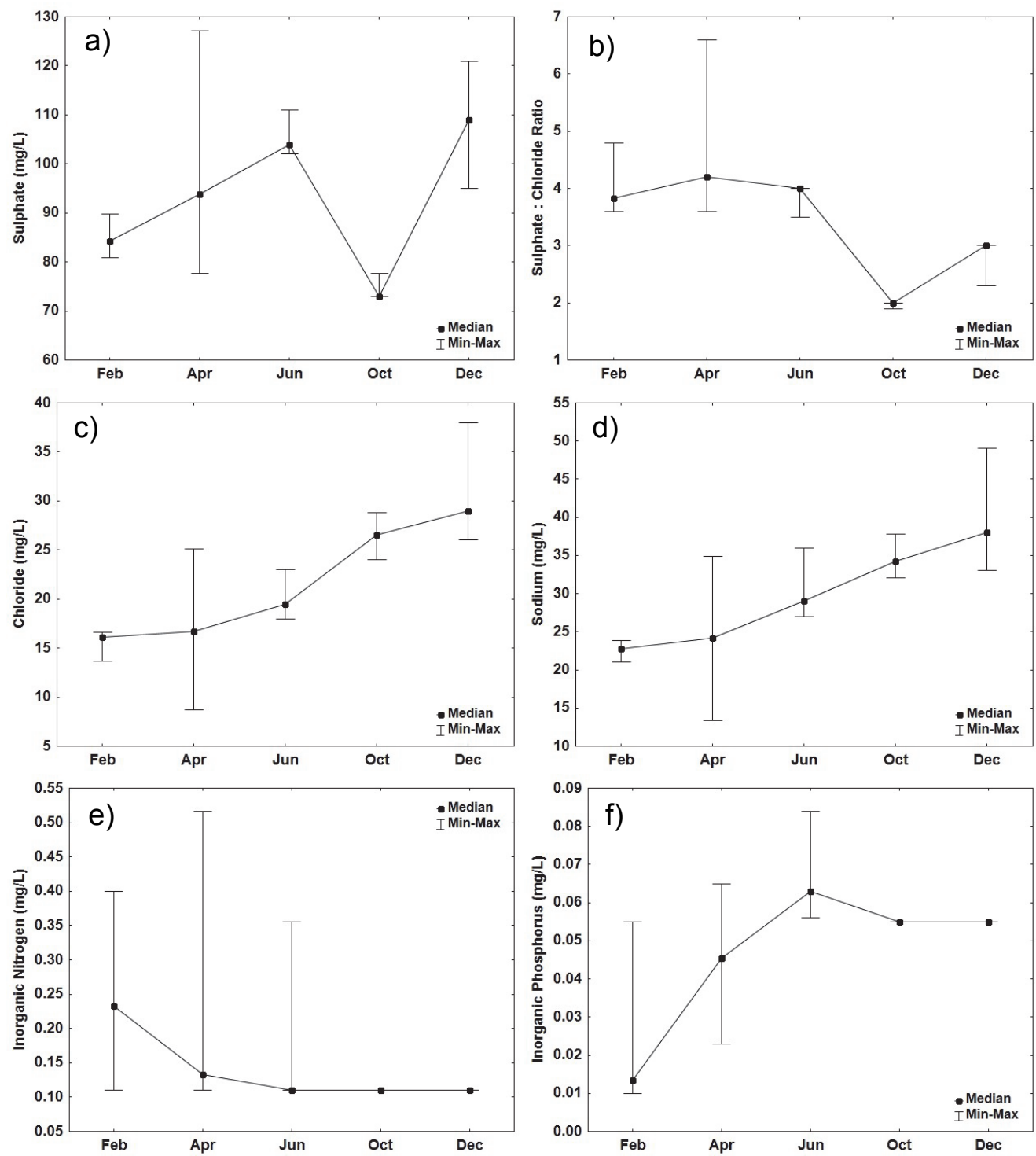

Figure 2

Seasonal variation in the median and range of selected surface water quality constituents measured in Flag Boshielo Dam during 2011
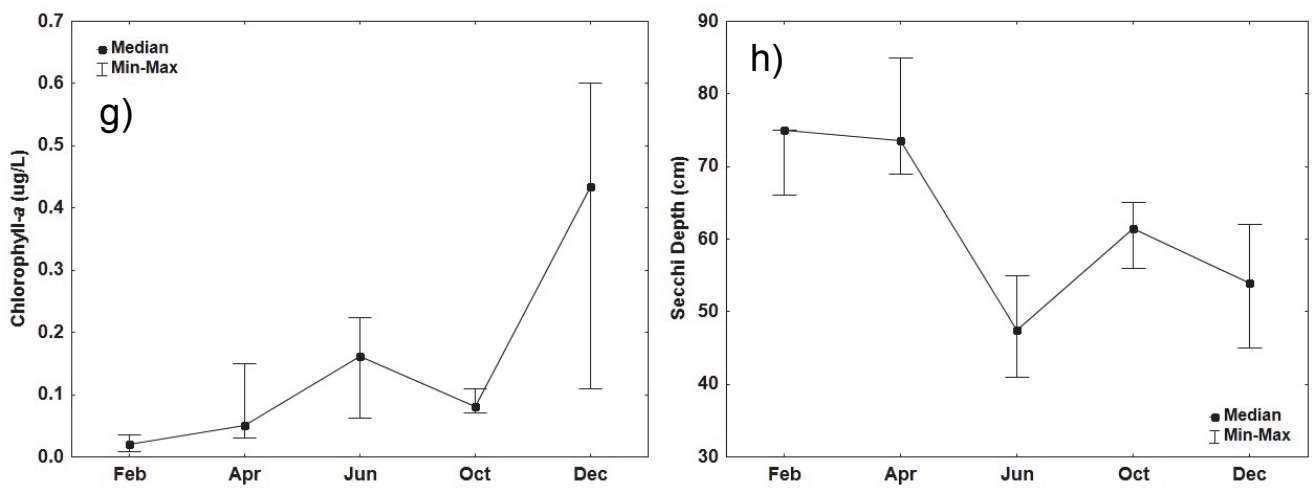

between Secchi depths and chlorophyll- $a$ concentrations (Fig. $2 \mathrm{~g}$ and $\mathrm{h}$ ). Chlorophyll- $a$ concentrations were generally low with a median of $0.08 \mu \mathrm{g} / \ell$ and a maximum of $0.6 \mu \mathrm{g} / \ell$ which was measured in December (Table 2). No algal blooms were observed during the study period. Total suspended solids (TSS) and turbidity were not monitored as part of this study; however, DWA measured these parameters monthly at their site during 2011. To better explain the origins of turbidity, these results were included in Table 2 under Site FB3 as it is located near the DWA site. The background value for TSS was calculated as $5.68 \mathrm{mg} / \ell$, which was the median of the DWA dataset ranging from 2006 until $2011(n=40)$. In June the TSS measured $21.2 \mathrm{mg} / \ell$, which was $>10 \%$ of the background value and therefore exceeded the TWQR. However, the background value is well within range of the guideline for all aquatic ecosystems of $<100 \mathrm{mg} / \ell$ (DWAF, 1996a). Turbidity values were below detection limits in February and April, and were below 2 NTU in June, October and December. The median concentration of dissolved organic carbon was $8 \mathrm{mg} / \ell$ which was fairly consistent in different seasons and across sites in the dam. Silica 


\begin{tabular}{|c|c|c|c|c|c|c|c|c|c|c|c|c|c|c|c|c|c|c|c|c|c|c|}
\hline & * Turbidity (NTU) & 至 & $\mathrm{z}$ & $\mathrm{z}$ & $\theta$ & $\mathrm{z}$ & 要 & $\mathrm{z}$ & $\mathrm{z}$ & 吾 & 安 & & z & 至 & $\mathrm{z}$ & $\stackrel{n}{\circ}$ & & 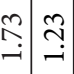 & ج্ণ & $\stackrel{\overbrace{}}{\rightarrow}$ & ?? & $\stackrel{n}{c}$ \\
\hline & * Total suspended solids (mg/l) & $\mathrm{z}$ & $\mathrm{z}$ & $\mathrm{z}$ & 要 & $\mathrm{z}$ & 要 & & 命 & 吾 & 吾 & & 定 & 至 & 命 & r & $\stackrel{\overbrace{}}{\pi}$ & \begin{tabular}{c|c}
$\sim$ & $\infty$ \\
& $\stackrel{\infty}{*}$ \\
\end{tabular} & $\cong$ & $\stackrel{+}{\therefore}$ & مُ & $\frac{\sim}{\sim}$ \\
\hline & Secchi depth $(\mathrm{cm})$ & $\because$ & $\infty$ & 뉴 & تี & के & $i$ & 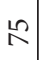 & $\exists$ & ᄂ & \& & 58 & 8 & in & ชู & $\mathrm{z}$ & N & $\ln 2: 8$ & in & ชర & $\exists:$ & $\infty$ \\
\hline $\bar{c}$ & Silica (Si; mg/l) & $\begin{array}{l}4 \\
6 \\
6\end{array}$ & $\stackrel{+}{-}$ & $\stackrel{m}{m}$ & {$\left[\begin{array}{ll}n \\
i n\end{array} \mid\right.$} & 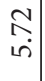 & $\mathscr{F}$ & $\stackrel{\infty}{i}$ & $\begin{array}{l}\bullet \\
\dot{m}\end{array}$ & in & 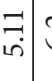 & ֶֶ: & $\vec{m}$ & $\stackrel{\sim}{\sim}$ & 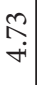 & 0 & $\hat{b})$ & 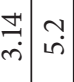 & 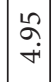 & $\left(\begin{array}{c}n \\
\text { in }\end{array}\right)$. & $\stackrel{2}{:}$ & \\
\hline 趇 & $\begin{array}{l}\text { Dissolved Organic Carbon } \\
\text { (mg/l/) }\end{array}$ & $\begin{array}{l}\infty \\
0 \\
i n \\
i n\end{array}$ & + & $\infty$ & $\wedge$ & $\infty$ & $\mid \begin{array}{l}0 \\
2 \\
i n\end{array}$ & $\infty$ & a & $\infty$ & $a$ & ڤે. & 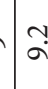 & $\infty$ & $\infty$ & 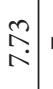 & $\wedge$ & $\sigma: \wedge$ & $\infty$ & $\infty$ & $\pi \mid$ & תִ. \\
\hline$\frac{0}{\stackrel{0}{\varrho}}$ & Chlorophyll-a $(\mu \mathrm{g} / \ell)$ & $\begin{array}{l}0 \\
\dot{o} \\
\dot{O}\end{array}$ & 官 & \begin{tabular}{l}
$\infty$ \\
\multirow{1}{0}{} \\
0
\end{tabular} & $=$ & $\tilde{\omega}$ & $\mid \begin{array}{l}n \\
0 \\
0 \\
0\end{array}$ & $\begin{array}{l}n \\
0 \\
0\end{array}$ & $\begin{array}{l}1 \\
\vdots \\
\vdots \\
0\end{array}$ & 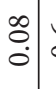 & $\stackrel{0}{0}$ & \begin{tabular}{lll}
0 \\
\hdashline \\
0 \\
0
\end{tabular} & 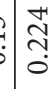 & $\mid \begin{array}{l}\infty \\
0 \\
0 \\
0\end{array}$ & 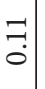 & $\begin{array}{l}\stackrel{L}{a} \\
\vdots \\
0\end{array}$ & $\begin{array}{c}8 \\
0 \\
\vdots\end{array}$ & 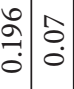 & $\mid \begin{array}{l}n \\
i \\
0 \\
0\end{array}$ & 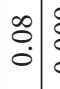 & & \\
\hline $\begin{array}{l}\infty \\
\text { o } \\
\frac{\pi}{L}\end{array}$ & Manganese $(\mathrm{Mn} ; \mu \mathrm{g} / \mathrm{\ell})$ & $\left|\begin{array}{ll}n: \\
\text { in: }\end{array}\right|$ & {$\left[\begin{array}{ll}n \\
i n\end{array}\right]$} & 의 & $\vec{m}$ & 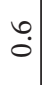 & inn & in & 의 & $\vec{m}$ & $?$ & & : & $\mid$ & $?$ & 剈 & 织 & $\therefore$ 감 & $\tilde{0}$ & in & 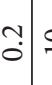 & \\
\hline 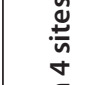 & Iron $(\mathrm{Fe} ; \mu \mathrm{g} / \mathrm{\ell})$ & $\mid \begin{array}{l}n \\
\stackrel{2}{N}\end{array}$ & $\stackrel{\sim}{\circ}$ & เn: & \begin{tabular}{|l} 
\\
$\stackrel{I}{I}$
\end{tabular} & \begin{tabular}{l}
2 \\
$\infty$ \\
$\infty$ \\
\hdashline
\end{tabular} & $\begin{array}{l}n \\
\stackrel{n}{N} \\
\end{array}$ & iి & in & $\stackrel{\overbrace{}}{=}$ & $\stackrel{r}{i}$ & 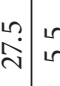 & $\begin{array}{l}\text { ? } \\
\text { in }\end{array}$ & $?$ & $\ddot{a}$ & $\stackrel{n}{\stackrel{n}{\sim}}$ & 贻 & เి & $\stackrel{n}{0}$ & $\stackrel{m}{2}$ & $\begin{array}{lll}n \\
0 \\
0\end{array}$ & \\
\hline $\begin{array}{l}\frac{\tilde{L}}{\breve{y}} \\
\frac{\tilde{u}}{a}\end{array}$ & Aluminium $(\mathrm{Al} ; \mu \mathrm{g} / \mathrm{\ell})$ & $=$ & $=$ & $=$ & 守 & $\stackrel{m}{+}$ & $=$ & $=$ & $=$ & $\stackrel{\vartheta}{\exists}$ & $\stackrel{?}{:}=$ & $\Rightarrow=$ & $=$ & $\mid \begin{array}{l}\infty \\
\dot{0}\end{array}$ & $\begin{array}{l}\dot{0} \\
\infty\end{array}$ & $=$ & $\Rightarrow=$ & $=\underset{r}{\stackrel{F}{*}}$ & $\stackrel{+}{=}$ & & & \\
\hline 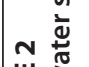 & $\mathrm{SO}_{4}: \mathrm{Cl}$ ratio & in & $\wedge$ & + & $\sim$ & $\sim$ & $\psi$ & in & + & $n$ & $m$. & $+\theta$ & $H$ & $\sim$ & $m$ & + & $+\gamma$ & $r \mid c$ & $m$ & $H$ & $4 h$ & \\
\hline 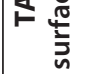 & Sulphate $\left(\mathrm{SO}_{4} ; \mathrm{mg} / \mathrm{\ell}\right)$ & 2 & $\infty$ & $\Xi$ & $\infty$ & $\vec{\exists}$ & $\infty$ & 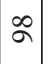 & 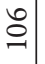 & $\bumpeq$ & $\stackrel{\Xi}{\exists}$ & $\vec{\infty} \triangleq$ & $\approx$ & 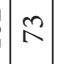 & 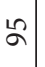 & $\bar{\infty}$ & $\infty$ & $\begin{array}{lll}0 & \Re & \Re\end{array}$ & 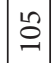 & mi & $\curvearrowright$ & \\
\hline$\stackrel{5}{5}$ & Total Alkalinity $\left(\mathrm{CaCO}_{3^{\prime}}\right.$ mg// $)$ & 8 & 아 & $\Re$ & 산 & $\wedge$ & R & กे & $\infty$ & $\mathfrak{N} \S$ & \&ิ & $\cong \infty$ & in & 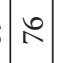 & $\infty$ & $R$ & 58 & $\begin{array}{lll}\hat{6} & 2 \\
1\end{array}$ & ה & $R$ & 위: & \\
\hline $\begin{array}{l}\stackrel{\Xi}{\sim} \\
\stackrel{.}{\Xi}\end{array}$ & DIN:DIP ratio & $\hat{i}$ & $\underset{\infty}{-a}$ & $\begin{array}{l}\stackrel{+}{\infty} \\
+ \\
+\end{array}$ & 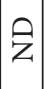 & 安 & $\left|\begin{array}{|c}\hat{0} \\
\dot{0} \\
\dot{m}\end{array}\right|$ & $\vec{m}$ & $\hat{\circ}$ & 至 & 至 & $\stackrel{2}{\curvearrowright}$ & $\stackrel{9}{-}$ & $\hat{z}$ & $\hat{z}$ & $\underset{\infty}{\infty} \mid$ & $\stackrel{\infty}{\infty}=$ & $=\theta$ & 至 & 学 & & $\hat{\mathrm{N}}$ \\
\hline 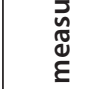 & \begin{tabular}{|l} 
Dissolved inorganic nitrogen \\
(DIN; mg/ $/$ )
\end{tabular} & $\ddot{0}$ & $\begin{array}{ll}0 \\
0 \\
0\end{array}$ & $\begin{array}{l}\tilde{n} \\
\stackrel{0}{0}\end{array}$ & a.t. & a. & $\mid \begin{array}{l}n \\
m \\
0 \\
0\end{array}$ & : & $\begin{array}{l}10 \\
0 \\
0\end{array}$ & al & $\overrightarrow{0}$ & $\because \overline{0}$ & $=$ & : & $\overrightarrow{0}$ & $=$ & $\overrightarrow{0}=$ & 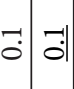 & an & all & & ?? \\
\hline 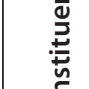 & $\begin{array}{l}\text { Dissolved Inorganic phosphorus } \\
\text { (DIP; mg/l) }\end{array}$ & $\mid \begin{array}{l}2 \\
0 \\
0 \\
0\end{array}$ & $\begin{array}{l}n \\
0 \\
0 \\
0\end{array}$ & $\begin{array}{l}2 \\
⿱ \\
\vdots \\
0\end{array}$ & $\begin{array}{ll}2 \\
0 \\
0 \\
0\end{array}$ & \begin{tabular}{l}
0 \\
\hdashline \\
0
\end{tabular} & $\overrightarrow{0}$ & $\begin{array}{l}0 \\
0 \\
0 \\
0\end{array} \mid$ & $\begin{array}{l}1 \\
0 \\
0 \\
0 \\
0\end{array}$ & \begin{tabular}{l|l}
2 & \\
0 &
\end{tabular} & \begin{tabular}{l}
$n$ \\
\hdashline \\
0
\end{tabular} & \begin{tabular}{c|c}
\multirow{2}{*}{} \\
$\vdots$ \\
0
\end{tabular} & $\begin{array}{l}0 \\
\vdots \\
\vdots\end{array}$ & $\mid \begin{array}{l}2 \\
0 \\
0 \\
0\end{array}$ & $\begin{array}{l}\stackrel{0}{0} \\
0 \\
0\end{array}$ & $\begin{array}{l}m \\
\vdots \\
0 \\
0\end{array}$ & \begin{tabular}{l|l}
$\tilde{c}$ & 5 \\
0 & \\
0
\end{tabular} & 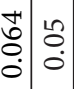 & $\begin{array}{l}2 \\
0 \\
0 \\
0\end{array}$ & \begin{tabular}{l|l}
2 & \\
0 \\
0 \\
0
\end{tabular} & & $\begin{array}{l}+1 \\
0 \\
0\end{array}$ \\
\hline 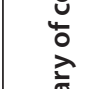 & Dissolved oxygen $(\mathrm{mg} / \mathrm{l})$ & 穴 & $\begin{array}{l}\overrightarrow{0} \\
\stackrel{1}{0}\end{array}$ & 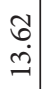 & $\begin{array}{l}0 \\
\stackrel{0}{ } \\
\end{array}$ & $\begin{array}{l}\tilde{\sim} \\
\dot{\Xi} \\
\end{array}$ & $\begin{array}{l}\sharp \\
\stackrel{1}{0} \\
\stackrel{0}{*}\end{array}$ & $\begin{array}{c}\stackrel{\sigma}{\infty} \\
\infty \\
\infty\end{array}$ & $\begin{array}{l}\stackrel{2}{0} \\
\dot{j}\end{array}$ & $\stackrel{7}{\circ}$ & $\begin{array}{l}\hat{a} \\
\text { i }\end{array}$ & \begin{tabular}{l|l}
$\exists$ \\
\multirow{0}{*}{} \\
0
\end{tabular} & $\stackrel{\varrho}{\varrho}$ & \begin{tabular}{l}
8 \\
\hdashline \\
\end{tabular} & 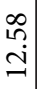 & 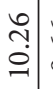 & \begin{tabular}{l|l} 
& $\vdots$ \\
$\vdots$ & \\
$\infty$ &
\end{tabular} & 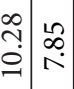 & $\underset{\infty}{\not}$ & $\begin{array}{lll}\tilde{a} & \\
\stackrel{0}{0} & \end{array}$ & 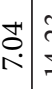 & 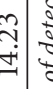 \\
\hline$\stackrel{\xi}{\underline{\xi}}$ & Electrical Conductivity $(\mu \mathrm{S} / \mathrm{cm})$ & $\mid \begin{array}{l}n \\
n \\
m\end{array}$ & $\mid \begin{array}{l}\vec{\infty} \\
m\end{array}$ & $\stackrel{\vec{f}}{+}$ & $\vec{n}$ & $\begin{array}{l}\text { D } \\
\text { in }\end{array}$ & 손 & 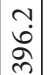 & 突 & ஓे & 命 & 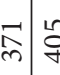 & $\stackrel{\infty}{\infty}$ & 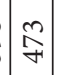 & $\stackrel{\Re}{\stackrel{2}{f}}$ & oे & 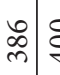 & 各 & $\begin{array}{l}n \\
0 \\
0 \\
0\end{array}$ & 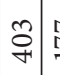 & 今心 & in \\
\hline & $\mathrm{pH}$ & $\stackrel{\curvearrowright}{\curvearrowright}$ & $\begin{array}{c}\infty \\
\stackrel{\infty}{n} \\
\end{array}$ & 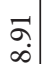 & $\left.\mid \begin{array}{ll}\infty \\
0 \\
0 \\
\vdots\end{array}\right]$ & $\widehat{\partial}$ & $\left|\begin{array}{c}0 \\
0 \\
\infty \\
\infty\end{array}\right|$ & $\left|\begin{array}{cc}\infty \\
\vdots \\
\infty \\
\infty\end{array}\right|$ & $\begin{array}{c}\infty \\
\infty \\
\infty \\
\infty\end{array}$ & $\begin{array}{lll}\hat{a} \\
\partial \\
0\end{array}$ & ‡ุa & $\vec{a}$ & $\begin{array}{l}\stackrel{0}{2} \\
\infty \\
\infty\end{array}$ & 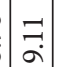 & $\ddot{2}$ & $\stackrel{2}{a}$ & 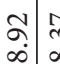 & 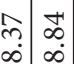 & $\left|\begin{array}{l}+1 \\
\vdots \\
\infty\end{array}\right|$ & $\mid \begin{array}{ccc}0 & 1 \\
2 & 0 & 1 \\
0 & 1 & 1\end{array}$ & $\stackrel{\infty}{\sim}$ & F \\
\hline & Date & & & & 0 & a & $\begin{array}{l}0 \\
0 \\
0 \\
w\end{array}$ & 妾 & $\Xi$ & o. & ค & 章 & & $\overrightarrow{\breve{o}}$ & $\ddot{\check{~}}$ & 产. & 赵 & $\Xi \breve{O}$ & : & & & \\
\hline & Site & $\vec{I}$ & & & & & 馬 & & & & & مै & & & & 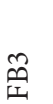 & & & & & $\dot{\xi}$ & $\doteq$ \\
\hline
\end{tabular}



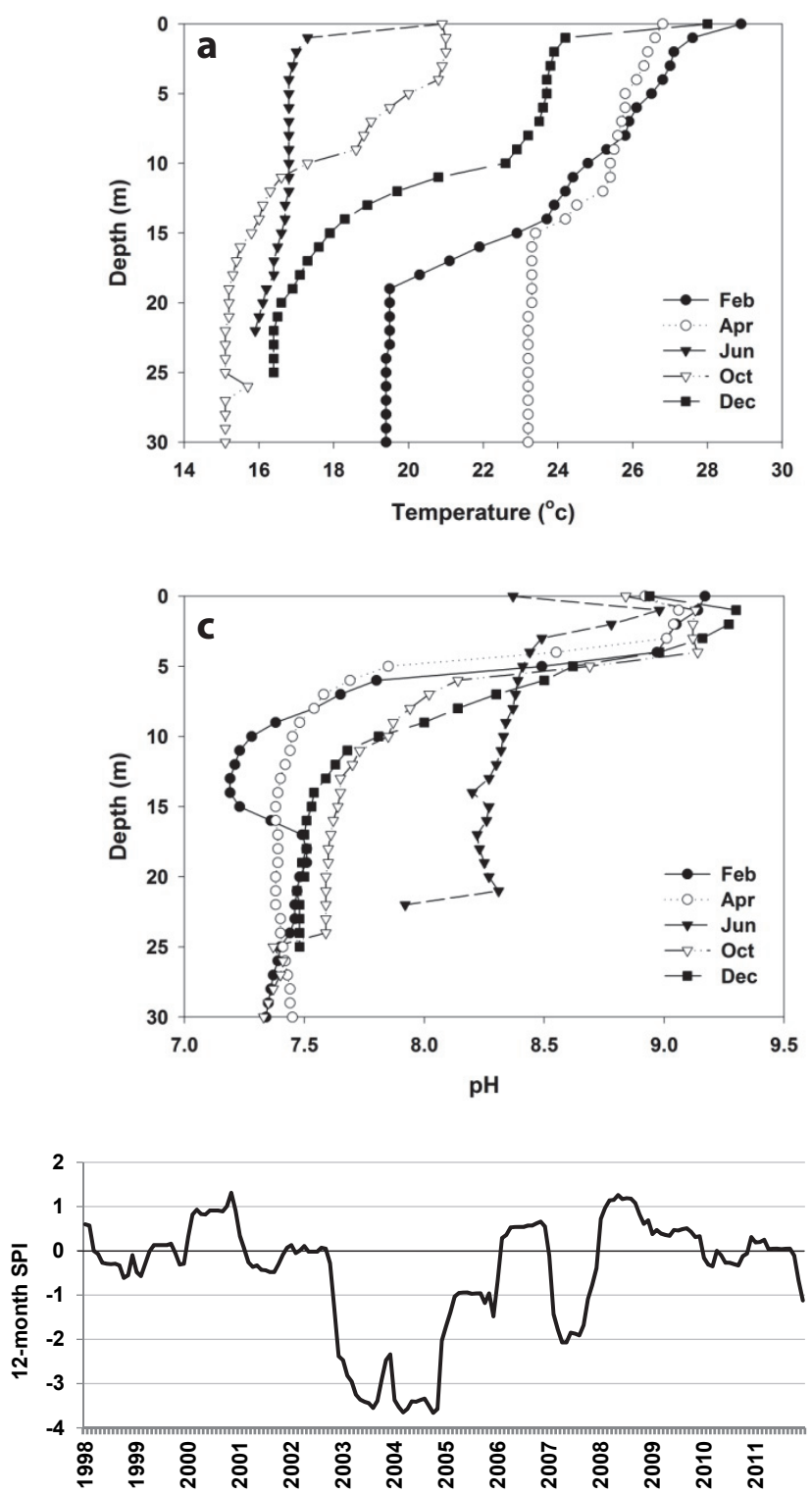

Figure 4

Selected time series from January 1998 to December 2011 of 12-month SPI values for the Loskop Irrigation Board rainfall station. Calculations were based on long-term records from 1952 until 2011.

concentrations ranged widely from $1.4 \mathrm{mg} / \ell$ to $10.1 \mathrm{mg} / \ell$, with no clear seasonal or spatial trends across the dam (Table 2).

\section{Reservoir profiles}

Flag Boshielo Dam demonstrated a typical monomictic mixing regime. Turnover occurred between April and June, which was the only period when approximately isothermal conditions were observed, at around $16^{\circ} \mathrm{C}$ (Fig. 3a). Surface heating commenced from October onwards, resulting in well-defined thermal stratification from October until February. Surface water temperatures varied substantially from $21^{\circ} \mathrm{C}$ in June to $28^{\circ} \mathrm{C}$ in February. During periods of stratification, dissolved oxygen (Fig. 3b) and $\mathrm{pH}$ values (Fig. 3c) were elevated at the surface. Distinct oxyclines around $10 \mathrm{~m}$ depth were evident, where values decreased from between 6 and $10 \mathrm{mg} / \ell$ at the surface, to anoxic conditions in the hypolimnion in all months except June

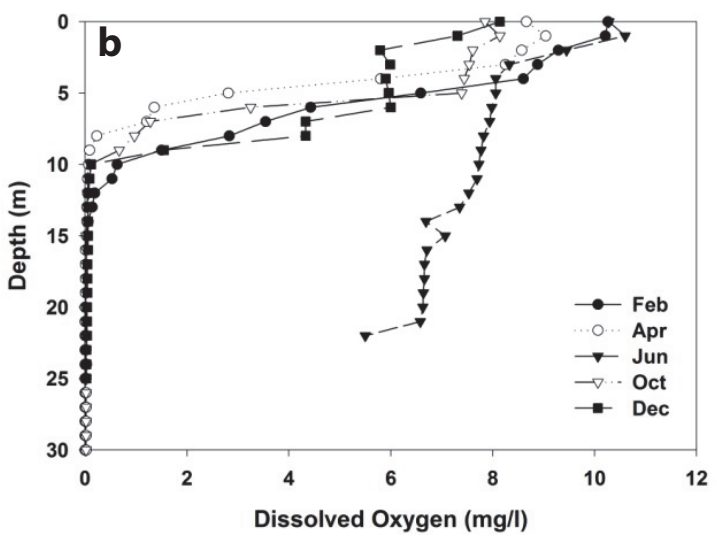

Figure 3 (above and left)

Field measurement profiles of temperature (a), dissolved oxygen (b) and pH (c), collected during 2011 at Site FB3 near the dam wall of Flag Boshielo Dam.

(Fig. 3b). The $\mathrm{pH}$ followed a similar trend to dissolved oxygen, with values of approx. 9 in the upper $5 \mathrm{~m}$, decreasing to between 7 and 8.8 in the metalimnion and hypolimnion (Fig. 3c).

\section{Drought characterisation}

The 12-month SPI results from all 3 rainfall stations were positively correlated with dam level (\%), but values from the Loskop Irrigation Board showed the strongest correlation (Spearman's $\left.r_{s}=0.61 ; p<0.001\right)$ and are presented in Fig. 4 . The rainfall station is located downstream of Loskop Dam, and adjacent to the Olifants River $(-25.4 ; 29.367)$. Although data from 1952 to 2011 were used to determine the 12-month SPI, only the time period from 1998 to 2011 was presented (Fig. 4) as it corresponded to the DWA monitoring period. There was an extended drought between November 2002 and December 2005. During this period the SPI dropped below zero and was frequently around -3.00 , which was representative of extreme drought conditions. This event was typified by the lowest SPI values in the longterm data from 1952 to 2011 at this station.

During the drought, prolonged low flows from the Olifants and Elands rivers resulted in very low water levels in Flag Boshielo Dam (Fig. 5). The lowest water level was recorded at $7.7 \mathrm{~m}$ (23.7\% of FSL) in February 2004. At this point the area exposed was equivalent to $8.14 \mathrm{~km}^{2}$, or $63 \%$ of the surface area of the reservoir at FSL (1997 sediment survey, DWA Spatial and Land Information Management). The water level rose briefly in early 2004, but was not sustained due to consistently low inflow volumes. Renewed high flows in February 2006 coincided closely with raising the dam wall by $5 \mathrm{~m}$ in March 2006, although the two events were unrelated. Construction work to raise the dam wall did not require any release of water to enable work to proceed, and low water 


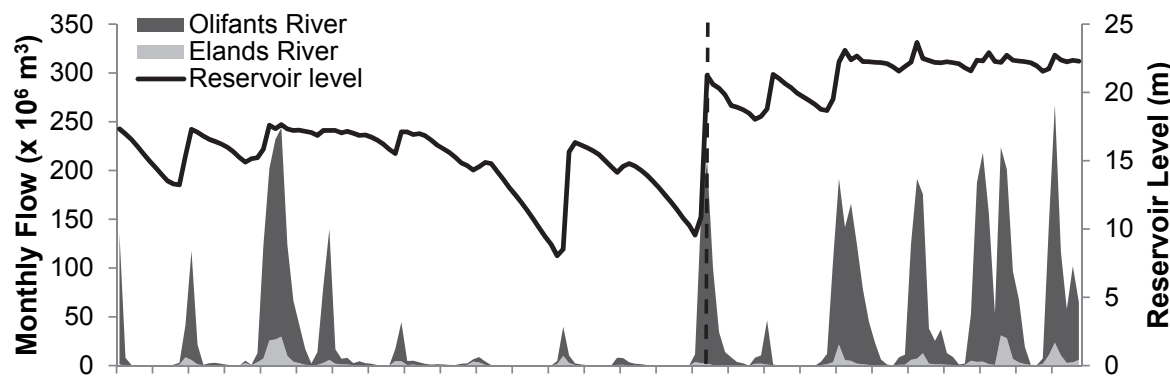

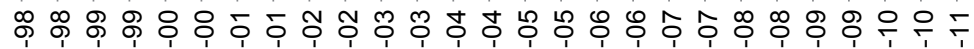

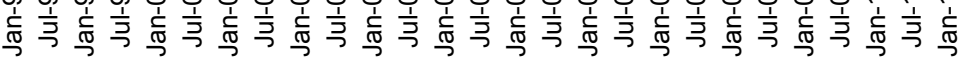

Figure 5

Monthly water levels in Flag Boshielo Dam plotted with monthly inflow values from the Olifants River (DWA site B3H001) and Elands River (DWA site B3H021) between 1998 and 2011. The dashed vertical line represents the end of $a$ drought that coincided with the completion of the raised dam wall in March 2006. levels prior to completion of construction were purely related to the drought.

\section{Department of Water Affairs monitoring data}

The only parameters with a relatively high proportion of censored data were dissolved inorganic $\mathrm{P}$ and $\mathrm{N}$, total suspended solids, and chlorophyll- $a$. However, the proportions were less than $50 \%$ allowing trends to be analysed. All parameters were monitored regularly from 1998 , except total P, total N, chlorophyll- $a$, and TSS, which were only monitored from ca. 2005 onwards. Trends could not be calculated for Secchi depth as no measurements before 2012 were available.

Mean annual chlorophyll- $a$ concentrations classified the reservoir as oligotrophic with a moderate nuisance value for algal bloom productivity (Table 3 ). Mean annual total $\mathrm{P}$ concentrations represented a moderate potential for algal or plant productivity (Table 3). Both moderate classifications are fairly low because there are 2 categories (significant and serious) above this level.

\begin{tabular}{|l|l|l|l|}
\hline \multicolumn{4}{|c|}{ TABLE 3} \\
Trophic status and eutrophication potential of Flag Boshielo Dam calculated using DWA monitoring data collected \\
between 2005 and 2011 (DWAF, 2002)
\end{tabular}

TABLE 4

Summary of the seasonal Mann-Kendall trend analysis performed on LOWESS residuals adjusted for dam level $(\mathrm{m})$ for the entire range of the dataset. Results of the Spearmans rank correlation $\left(r_{s}\right)$ between dam level $(\mathrm{m})$ and each parameter are included, along with median values of each parameter after the dam wall was raised and high flows resumed in March 2006.

\begin{tabular}{|c|c|c|c|c|c|c|}
\hline Parameter & Data range $(n)$ & $\begin{array}{l}\% \\
\text { Censored }\end{array}$ & Spearmans $r_{s}$ & $\begin{array}{l}\text { Median post } \\
\text { March } 2006\end{array}$ & Trend & Kendall's Tau \\
\hline $\mathrm{pH}$ (standard units) & 1998-2011 (156) & 0 & $-0.53^{\star * \star}$ & 7.9 & - & $-0.273^{\star * *}$ \\
\hline Electrical conductivity $(\mu \mathrm{S} / \mathrm{cm})$ & 1998-2011 (154) & 0 & $-0.76^{\star * *}$ & 444.75 & + & $0.384^{* * *}$ \\
\hline Calcium $\mathrm{Ca}^{2+}(\mathrm{mg} / \ell)$ & 1998-2011 (155) & 0 & $-0.47^{* * *}$ & 29.2 & 0 & 0.023 \\
\hline Magnesium $\mathrm{Mg}^{2+}(\mathrm{mg} / \mathrm{\ell})$ & 1998-2011 (151) & 0 & $-0.37^{* * *}$ & 18.1 & + & $0.154^{*}$ \\
\hline Potassium $\mathrm{K}^{+}(\mathrm{mg} / \ell)$ & 1998-2011 (138) & 0 & $-0.6^{* * *}$ & 4.9 & 0 & 0.066 \\
\hline Sodium $\mathrm{Na}^{+}(\mathrm{mg} / \mathrm{\ell})$ & 1998-2011 (149) & 0 & $-0.81^{* * *}$ & 27.03 & - & $-0.179 *$ \\
\hline Sodium adsorption ratio & 1998-2011 (153) & 0 & $-0.81^{* * *}$ & 1 & - & $-0.197^{\star}$ \\
\hline Chloride $\mathrm{Cl}^{-}(\mathrm{mg} / \mathrm{\ell})$ & 1998-2011 (149) & 0 & $-0.75^{* * *}$ & 23 & + & $0.336^{* * *}$ \\
\hline Fluoride $\mathrm{F}^{-}(\mathrm{mg} / \ell)$ & 1998-2011 (138) & 0 & $-0.68^{* * *}$ & 0.51 & 0 & 0.023 \\
\hline Sulphate $\mathrm{SO}_{4}^{2-}(\mathrm{mg} / \ell)$ & 1998-2011 (146) & 0 & -0.03 & 102.3 & + & $0.179 *$ \\
\hline Total alkalinity as $\mathrm{CaCO} 3(\mathrm{mg} / \mathrm{\ell})$ & 1998-2011 (148) & 0 & $-0.76^{\star * *}$ & 79.3 & 0 & -0.096 \\
\hline Total phosphorus (mg/l) & 2005-2011 (47) & 2 & 0.15 & 0.035 & 0 & 0.056 \\
\hline Total nitrogen $(\mathrm{mg} / \mathrm{\ell})$ & 2005-2011 (46) & 0 & -0.03 & 0.801 & - & $-0.5^{*}$ \\
\hline Dissolved inorganic phosphorus (mg/l) & 1998-2011 (149) & 43 & $-0.16^{*}$ & 0.014 & 0 & -0.093 \\
\hline Dissolved inorganic nitrogen $(\mathrm{mg} / \mathrm{\ell})$ & 1998-2011 (146) & 28 & -0.04 & 0.123 & - & $-0.294^{* * *}$ \\
\hline Inorganic $\mathrm{N}: \mathrm{P}$ ratio & 1998-2011 (141) & 7 & 0.04 & 5.41 & - & $-0.225^{*}$ \\
\hline Silica Si $(\mathrm{mg} / \mathrm{\ell})$ & 1998-2011 (149) & 0 & $-0.5^{\star * \star}$ & 5.14 & - & $-0.144^{\star}$ \\
\hline Sulphate:chloride Ratio & 1998-2011 (152) & 0 & $0.75^{* * *}$ & 3.21 & + & $0.129^{*}$ \\
\hline 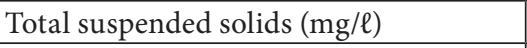 & $2006-2011(40)$ & 38 & -0.24 & 6.2 & 0 & 0.164 \\
\hline Chlorophyll- $a(\mu \mathrm{g} / \ell)$ & $2005-2011(46)$ & 34 & -0.11 & 6.85 & 0 & -0.167 \\
\hline
\end{tabular}

(+), upward trend; (-), downward trend; (0), no significant trend; (NS), Not Significant; (ND) Not Determined. Significance: ${ }^{* * *},<0.0001 ;{ }^{* *},<0.001 ; *$, $<0.05$ 

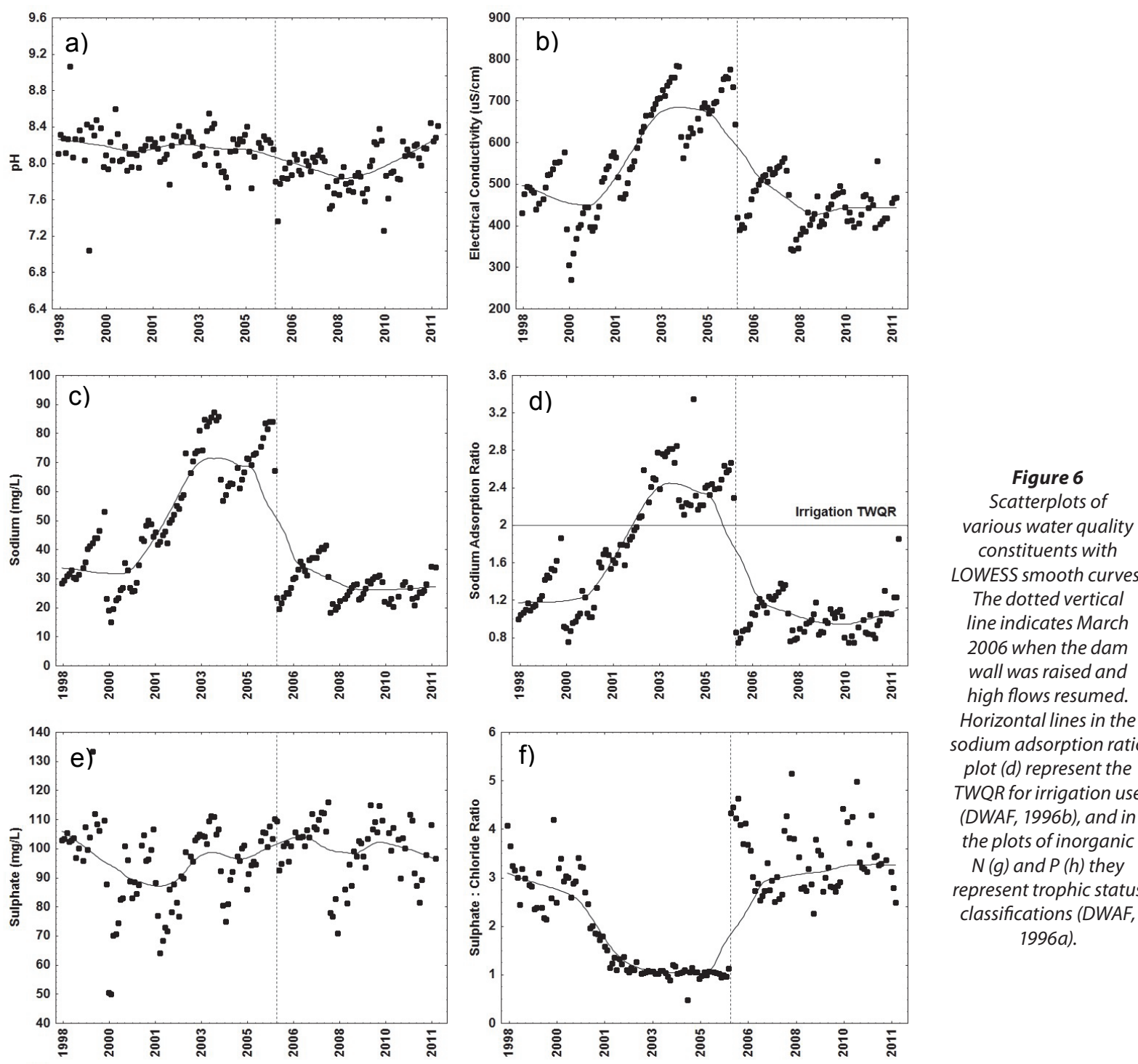

constituents with

LOWESS smooth curves.

The dotted vertical

line indicates March

2006 when the dam

wall was raised and

high flows resumed.

Horizontal lines in the

sodium adsorption ratio plot (d) represent the

TWQR for irrigation use (DWAF, 1996b), and in the plots of inorganic $N(g)$ and $P(h)$ they represent trophic status classifications (DWAF, 1996a).
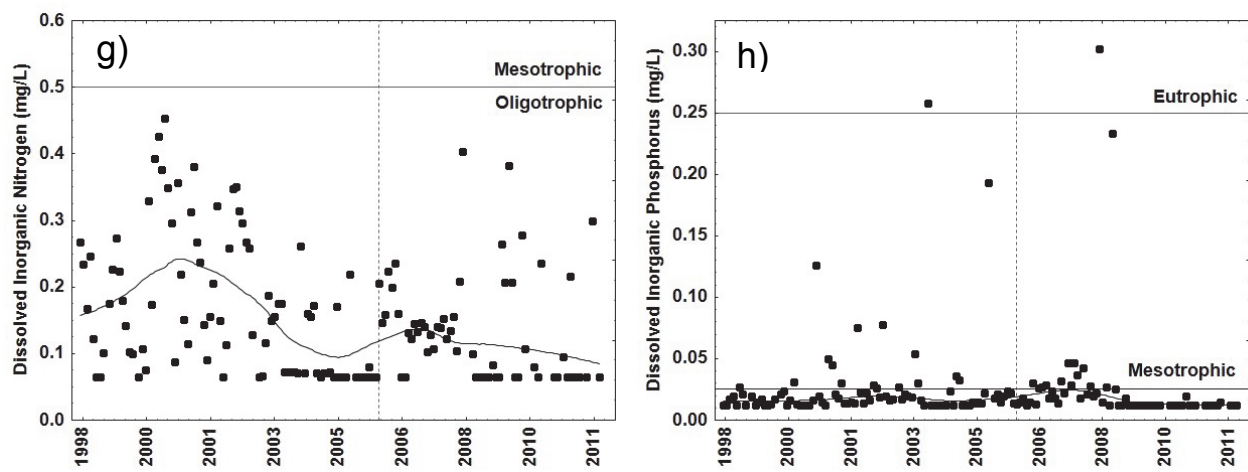

\section{Seasonal-Kendall trend analysis}

Results of the Spearman's rank correlation $\left(r_{s}\right)$ between dam level (m) and each parameter for the full duration of the data range are presented in Table 4. All major ions except sulphate showed significant negative correlations with dam level (i.e., as dam level $(X)$ increases, variable $(Y)$ concentration decreases). The only parameter that was positively correlated with dam level was the $\mathrm{SO}_{4}^{2-} / \mathrm{Cl}^{-}$ratio $\left(r_{s} 0.75\right)$. Parameters that were not significantly correlated with dam level were $\mathrm{SO}_{4}^{2-}$, total $\mathrm{P}$, total N, dissolved inorganic N, TSS and chlorophyll- $a$. Due to the drought and raising of the dam wall that influenced dam levels during the evaluation period (Fig. 4 and 5), the SeasonalKendall trend analysis was performed on LOWESS residuals adjusted for dam level (m) in order to evaluate long-term trends in parameters excluding variation related to this factor. No significant trends were observed for $\mathrm{Ca}, \mathrm{K}, \mathrm{F}$, total alkalinity, TSS or chlorophyll- $a$.

A significant decreasing trend in $\mathrm{pH}$ values was observed $($ Tau $=-0.273)$ and the median value after March 2006 was 7.9 (Table 4). However, the trend was very gradual and $\mathrm{pH}$ values were consistently alkaline with low variation (Fig. 6a). 


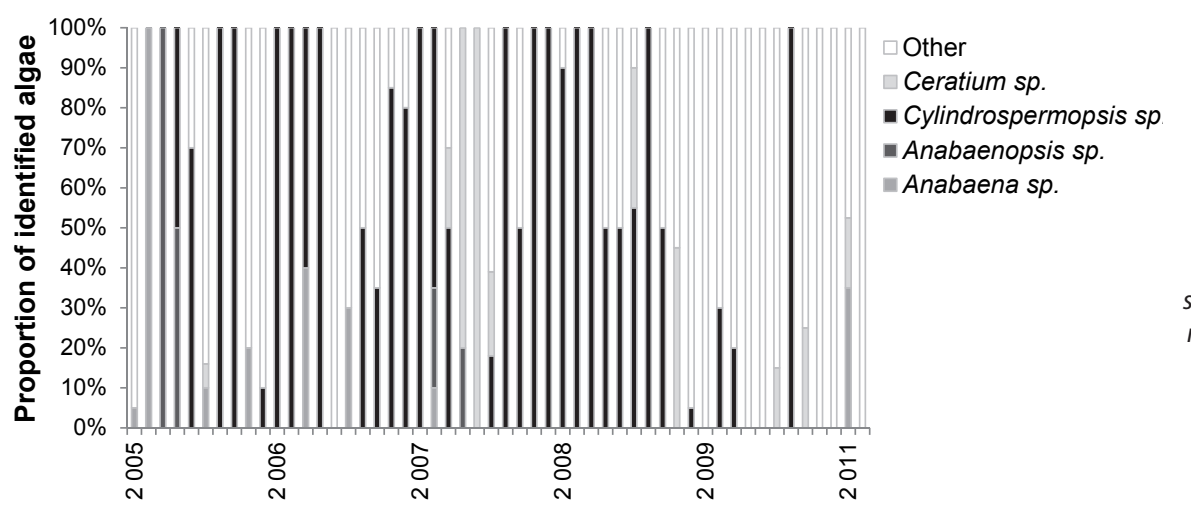

Figure 7

Proportional contribution of nitrogen-fixing species (Cylindrospermopsis sp.; Anabaenopsis sp., Anabaena $s p$.$) and Ceratium sp. identified in$ monthly phytoplankton samples collected by DWA between 2005 and 2011 in Flag Boshielo Dam
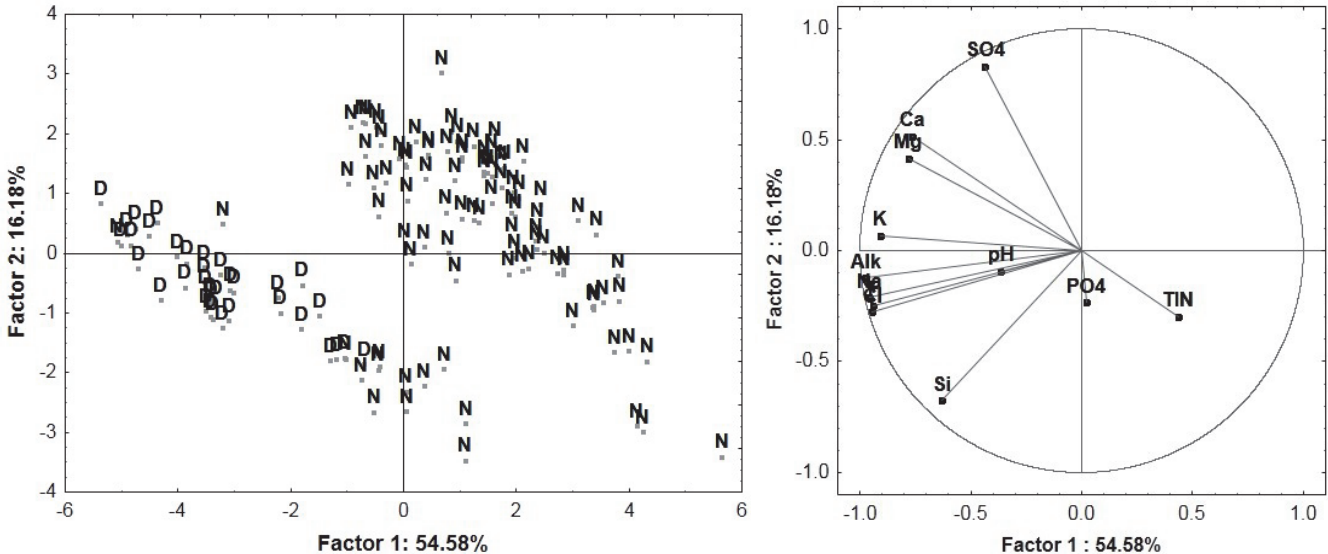

Figure 8

Principal component analysis (PCA) of the monthly median values for 11 water qaulity parameters measured by the DWA at Flag Boshielo Dam between 1998 and 2011. Samples were grouped according to collection date as either drought (D), between

November 2002 to

December 2005, or normal $(N)$, before and after this period.

Electrical conductivity showed a significant increasing trend $($ Tau $=0.384$; Table 4$)$ despite a substantial decrease in concentrations after the the dam wall was raised and normal flows resumed (Fig. 6b).

Sodium concentrations illustrated clear seasonal patterns that were evident for most parameters as diagonal lines of increasing concentrations over periods of time (Fig. 6c). These seasonal patterns spanned various time periods from less than 12 months to almost 24 months. A Spearman's rank correlation showed that $\mathrm{Na}$ and $\mathrm{Cl}$ concentrations were significantly positively correlated $\left(r_{s}=0.95 ; p<0.001\right)$, and patterns in the $\mathrm{Cl}$ data were almost identical to those for $\mathrm{Na}$ (Fig. 6c). Both $\mathrm{Na}$ and $\mathrm{Cl}$ showed the most significant negative correlations with dam level, at $r_{s}=-0.81$ and $r_{s}=-0.75$, repectively (Table 4), and concentrations of both ions dropped substantially after March 2006 (Fig. 6c). While Na showed a weakly significant negative trend over time (Tau $=-0.179), \mathrm{Cl}$ increased significantly over time $(\mathrm{Tau}=0.336$; Table 4$)$. During the drought, the sodium adsorption ratio continuously exceeded the TWQR for irrigation water which is $<2$ (Fig. 6d). However, post March 2006, the median value reduced to 1 and there was a significant decreasing trend over time $(\mathrm{Tau}=-0.197$; Table 4$)$.

Sulphate concentrations showed a significant increase over time $($ Tau $=0.179$; Table 4$)$, although this was a very gradual trend, and concentrations appeared more or less stable (Fig. 6e) The drought period did not appear to influence sulphate concentrations to a large degree, which was supported by the fact that $\mathrm{SO}_{4}{ }^{2-}$ was the only ion that was not significantly correlated with dam level (Table 4). While $\mathrm{SO}_{4}^{2-}$ concentrations remained relatively constant, the decrease in $\mathrm{Cl}$ concentrations after the dam wall was raised resulted in a significant increasing trend in the $\mathrm{SO}_{4}{ }^{2-} / \mathrm{Cl}^{-}$ratio $(\mathrm{Tau}=0.129)$ and the median value was 3.21 after March 2006 (Table 4).

The LOWESS trend-line for both inorganic $\mathrm{N}$ and $\mathrm{P}$ showed a small increase after the dam wall was raised from 2006 to 2007 , followed by a decrease from 2008 onwards (Fig. $6 \mathrm{~g}$ and $6 \mathrm{~h}$ ). Inorganic $\mathrm{N}$ showed a significant decreasing trend over time (Tau $=-0.294$; Table 4$)$, and concentrations never exceeded $0.5 \mathrm{mg} / \ell$, which classified Flag Boshielo Dam as oligotrophic (DWAF, 1996a). Total N also showed a significant decreasing trend $(\mathrm{Tau}=-0.5)$, but there was no trend in total $\mathrm{P}$ or inorganic $\mathrm{P}$ over time. The median inorganic $\mathrm{P}$ concentration after raising the dam wall was $0.014 \mathrm{mg} / \ell$ which also classified the reservoir as oligotrophic (DWAF, 1996a). The inorganic N:P ratio showed a significant decreasing trend (Tau $=-0.225)$; the median ratio of 5.41 after construction of the dam wall was indicative of $\mathrm{N}$ limitation (Table 4). Between 2006 and 2011 there was no significant monotonic trend in the chlorophyll- $a$ concentrations, and the median value was $6.85 \mu \mathrm{g} / \ell$ (Table 4).

The phytoplankton assemblage was generally dominated by nitrogen-fixing species, especially Cylindrospermopsis sp., between 2005 and 2008. No Microcystis spp. were detected throughout the monitoring period. Ceratium spp. were never dominant, and not frequently detected in samples (Fig. 7).

\section{Principal components analysis}

Results of the PCA of water samples collected during the drought from November 2002 until December 2005, and normal flows before and after this period, are presented in Fig. 8, with related factor loadings in Table 5. Only parameters that were measured from 1998 onwards were included in the analysis. There was a very clear distinction between water 


\section{TABLE 5}

Factor loadings of each water quality parameter in factor one and factor two from the PCA shown in Fig. 6

\begin{tabular}{|l|c|c|}
\hline Variable & Factor 1 & Factor 2 \\
\hline $\mathrm{pH}$ & -0.36 & -0.09 \\
\hline Calcium $\mathrm{Ca}^{2+}$ & -0.76 & 0.51 \\
\hline Magnesium $\mathrm{Mg}^{2+}$ & -0.78 & 0.41 \\
\hline Potassium $\mathrm{K}^{+}$ & -0.91 & 0.06 \\
\hline Sodium $\mathrm{Na}^{+}$ & -0.95 & -0.21 \\
\hline Chloride $\mathrm{Cl}^{-}$ & -0.94 & -0.27 \\
\hline Fluoride $\mathrm{F}^{-}$ & -0.93 & -0.24 \\
\hline Sulphate $\mathrm{SO}_{4}^{2-}$ & -0.43 & 0.83 \\
\hline Total alkalinity $\left(\mathrm{CaCO}_{3}\right)$ & -0.97 & -0.12 \\
\hline Dissolved inorganic $\mathrm{N}(\mathrm{DIN})$ & 0.43 & -0.29 \\
\hline Dissolved inorganic $\mathrm{P}(\mathrm{DIP})$ & 0.02 & -0.23 \\
\hline Silica Si & -0.62 & -0.67 \\
\hline
\end{tabular}

samples collected during both periods. The first and second factors accounted for $54.58 \%$ and $16.18 \%$ of the variation in the data, respectively. Drought water samples were characterised by high levels of dissolved salts, especially $\mathrm{K}, \mathrm{Na}, \mathrm{Cl}, \mathrm{F}$ and total alkalinity, all of which had factor loadings $>0.9$ in the first factor (Table 5). Sulphate had the strongest influence in the second factor (0.83) which separated samples collected during both normal flows and the drought period.

\section{DISCUSSION}

Results of short-term and long-term monitoring following the drought indicated that water quality in Flag Boshielo Dam was of a good standard from an ecosystem health perspective. On the basis of inorganic $\mathrm{N}$ and $\mathrm{P}$ measured during 2011, and long-term measurements of chlorophyll- $a$ and total P, Flag Boshielo Dam can be considered oligotrophic to mesotrophic, with N-limited primary production. In this respect it does not fit conventional assumptions that $\mathrm{P}$ is the yield-limiting nutrient for most South African impoundments (Toerien, 1975; Walmsley and Butty, 1980), and does not follow the trend of increasing eutrophication observed in many of our reservoirs (Van Ginkel, 2011), including Loskop Dam (Dabrowski et al., 2013; Oberholster et al., 2013). Given that irrigated and dryland agriculture dominate catchment land uses, providing a potential source of nutrients, this finding is both positive and remarkable.

While regular blooms of Microcystis aeruginosa and Ceratium hirundinella occur at Loskop Dam, no algal blooms occurred at Flag Boshielo Dam, and the phytoplankton assemblage was dominated by nitrogen-fixing species. Although $C$. hirundinella occurs in Flag Boshielo Dam, it was never dominant, and M. aeruginosa was never recorded between 2005 and 2011. Dissolved metal concentrations at Flag Boshielo Dam were consistently either below detection limits, or very low, while $\mathrm{Al}, \mathrm{Mn}$ and Fe periodically exceeded various thresholds of the water quality guidelines at Loskop Dam (Oberholster et al., 2010; Dabrowski et al., 2013). Furthermore, elevated concentrations of $\mathrm{Al}$ and $\mathrm{Fe}$ have been measured in the fat of $O$. mossambicus as well as in a potential food source, Spirogyra spp., from Loskop Dam (Oberholster et al., 2012). Of the metals measured at Flag Boshielo Dam during 2011, only Al was ever detected at levels that periodically exceeded the TWQR However, given the $\mathrm{pH}$ range at which these concentrations were measured ( $\mathrm{pH} 8.94$ - 9.39), the chemical speciation would predominantly have been in the form of relatively non-toxic $\mathrm{Al}$ hydroxides $\mathrm{Al}(\mathrm{OH})_{3}$ and $\mathrm{Al}(\mathrm{OH})_{4}^{-}$, as opposed to the highly toxic $\mathrm{Al}^{3+}$ which predominates below a $\mathrm{pH}$ of 5 (Gensemer and Playle, 1999).

The relatively shallow mean depth and high shoreline development value are factors that naturally increase the susceptibility of Flag Boshielo Dam to eutrophication (Dodds and Whiles, 2010). These factors are offset to an extent by the relatively short retention time of 4.9 months which increases flushing rates (Vollenweider, 1968). This is more than half the retention time of 12.2 months at Loskop Dam (Dabrowski et al., 2013). The reservoir showed a typical monomictic pattern of stratification, with prolonged anoxic conditions in the hypolimnion below $10 \mathrm{~m}$ during all sampling periods except June, when the water column was approximately holomictic. There was no indication of a deepening thermocline or oxycline related to lake turnover during sampling in April. This event occurred between late April and June. Elevated pH levels in the surface waters followed roughly the same pattern of stratification as dissolved oxygen up to around $10 \mathrm{~m}$. Through photosynthesis and the absorption of carbonic acid, phytoplankton growth is known to influence both of these variables (Wetzel, 1983).

Flag Boshielo Dam was moderately turbid throughout 2011, with Secchi depth values ranging from $0.62-0.85 \mathrm{~m}$. Turbidity was not obviously mineral in character because total suspended solids and turbidity values were not very high during 2011. However, the consistently low chlorophyll- $a$ concentrations indicated that algal productivity was also unlikely to influence turbidity to a great extent. The median dissolved organic carbon concentration of $8 \mathrm{mg} / \ell$ in 2011 could be considered moderate when compared to highly coloured rivers such as those in the Western Cape, where values range from $10 \mathrm{mg} / \ell$ to $21 \mathrm{mg} / \ell$ (Nkambule et al., 2012).

Water levels approximately doubled from $9.7 \mathrm{~m}$ in January 2006 to approx. $21 \mathrm{~m}$ in March 2006 following the drought, after which there was a clear pulse of inorganic $\mathrm{N}$ and $\mathrm{P}$ between 2006 and 2008. Although the water level in March 2006 only represented $90 \%$ of the new FSL, it was still around 4 $\mathrm{m}$ higher than the previous FSL. Newly inundated areas of the littoral zone including vegetation, and soils rich in organic matter and leaf litter, would have stimulated high levels of microbial decomposition, leading to an increase in nitrification and partially explaining the pulse of $\mathrm{N}$ and $\mathrm{P}$. Additional nutrients may have been released upon re-wetting of the sediments after the drought, a process caused by drying-induced microbial-cell lysis (Qiu and McComb, 1995; Baldwin and Mitchell, 2000). Although inorganic $\mathrm{N}$ was not significantly correlated with dam level, the LOWESS curve showed a distinct decrease in concentrations during the drought which contributed to the overall decreasing trend in inorganic $\mathrm{N}$. The reasons for lower inorganic $\mathrm{N}$ concentrations were not clear, but may include reduced inputs from the Olifants and Elands Rivers during the drought period. Alternatively, internal $\mathrm{N}$ loss associated with anoxic conditions during extended seasonal stratification is one of the main causes of $\mathrm{N}$ limitation in lakes at lower latitudes (Lewis, 2002).

Despite the flush of nutrients after re-wetting, inorganic $\mathrm{N}$ levels were still considered representative of oligotrophic conditions (DWAF, 1996a). Nutrient concentrations in lakes are known to show system-specific responses during extended drought periods, and after re-wetting. These include reductions, increases, and no change (Lake, 2011). These responses are governed by a variety of factors, such as the intensity and duration of drought, the extent of drying and oxidation levels 
of reservoir sediments, trophic status of the waterbody, and microbial activity associated with nutrient cycling (Lake, 2011). Increasing salinity, turbidity and alkalinity during periods of drought in lakes and rivers as a result of decreased dilution, increased evaporation, and increased residence time are well documented (Lake, 2011). Elevated salinity observed in the PCA during the drought in Flag Boshielo Dam was probably due to a combination of these factors, along with inputs of saline seepage associated with sub-surface agricultural return flows from the catchment (Loehr, 1984). The PCA showed that elevated salinity during the drought was characterised by high concentrations of $\mathrm{Na}, \mathrm{Cl}, \mathrm{K}, \mathrm{F}$ and total alkalinity. Concentrations of these ions reduced substantially when normal flows resumed in March 2006. The sodium adsorption ratio permanently measured $>2$ during the drought period, which exceeded the TWQR for irrigation purposes increasing the risk of Na uptake by sensitive crops (DWAF, 1996b). However, this value reduced to a median of 1 from March 2006 onwards, which was well within guideline levels.

Sulphate concentrations showed distinct seasonal variation, but were largely independent of water levels, as shown by the PCA and the Spearman's rank correlation. Fluctuations in the $\mathrm{SO}_{4}{ }^{2-} / \mathrm{Cl}^{-}$ratio were driven by low-flow mediated changes in $\mathrm{Cl}$ values, while sulphate was relatively stable. Values ranged from around 1 during the drought, to a median of 3.21 following resumed normal flows in March 2006. This value, along with the median $\mathrm{SO}_{4}{ }^{2-}$ concentration of $102.3 \mathrm{mg} / \ell$ suggested that the reservoir was influenced by treated and untreated acid mine drainage originating in the upper Olifants River catchment. However, the increasing trend in $\mathrm{SO}_{4}{ }^{2-}$ concentrations observed upstream in Loskop Dam (De Villiers and Mkwelo, 2009; Dabrowski et al., 2013) was not reflected in Flag Boshielo $\mathrm{Dam}$. The very gradual increasing trend in $\mathrm{SO}_{4}{ }^{2-}$ concentrations and very low levels of dissolved metals suggest that the effects of mining and industry on the water chemistry of Flag Boshielo Dam are currently limited, and are not yet a major cause for concern.

The results of this study emphasise the need to acknowledge and account for water levels (flow or reservoir level) when examining trends in long-term data sets. A case in point is the analysis of $\mathrm{Na}$ concentrations. Had the trend test been conducted prior to March 2006, not accounting for water levels, the $\mathrm{Na}$ concentrations would have shown an alarmingly steep increase that may have been attributed to other sources. The significant decreasing trend in $\mathrm{Na}$ concentrations after adjustment by LOWESS shows what occurs when water levels are held constant. However, aquatic biota experience the effect of actual concentrations and therefore both scenarios must be considered. Developing a hydrological model of Flag Boshielo Dam would be the next step in understanding the response of the system to changes in streamflow and water quality.

\section{CONCLUSIONS}

The aetiology of pansteatitis in captive-bred animals is dietary in nature and is recurrently ascribed to a diet high in polyunsaturated or rancid fats, and deficient in antioxidants (Larsen, 1983; Fytianou et al., 2006; Roberts and Agius, 2008). Oreochromis mossambicus are predominantly herbivores/detritivores. As primary consumers they are susceptible to quantitative and qualitative changes in primary producers. The difference in trophic state, phytoplankton assemblage and metal concentrations between both reservoirs emphasises the need to determine the diet of O. mossambicus from Loskop Dam, and establish its chemical and nutritional composition. A comparative study is required at the Olifants River gorge in the KNP to determine similarities and differences between this location and Loskop Dam.

\section{ACKNOWLEDGEMENTS}

The financial assistance of the National Research Foundation (NRF) towards this research is hereby acknowledged. Opinions expressed and conclusions arrived at, are those of the authors and are not necessarily to be attributed to the NRF. The authors wish to thank the Olifants River Forum for providing funding for this research. Field assistance from $\mathrm{Mr} \mathrm{N}$ Lubcker and $\mathrm{Mr}$ A Hoffman was invaluable and is sincerely appreciated. Dr D Helsel, Dr M Silberbauer (DWA), Dr S Jooste (DWA), and Dr $\mathrm{M}$ Claassen (CSIR) are thanked for their assistance with the manuscript and helpful discussions.

\section{REFERENCES}

APHA (AMERICAN PUBLIC HEALTH ASSOCIATION) (1998) Standard Methods for the Examination of Water and Wastewater $\left(20^{\text {th }}\right.$ edn). American Public Health Association (APHA), American Water Works Association (AWWA), and Water Pollution Control Federation (WPCF), Washington DC, USA.

ASHTON PJ (2010) The demise of the Nile crocodile (Crocodylus niloticus) as a keystone species for aquatic ecosystem conservation in South Africa: The case of the Olifants River. Aquat. Conserv: Mar. Freshwater Ecosyst. 20 489-493.

ASHTON PJ and DABROWSKI JM (2011) An overview of surface water quality in the Olifants River catchment. WRC Report No. KV 293/11. Water Research Commission, Pretoria.

BALDWIN DS and MITCHELL AM (2000) The effects of drying and re-flooding on the sediment and soil nutrient dynamics of lowland river - floodplain systems: A synthesis. Regul. Rivers: Res. Manage. 16 457-467.

BOTHA PJ (2010) The distribution, conservation status and blood biochemistry of Nile crocodiles in the Olifants River system, Mpumalanga, South Africa. Unpublished PhD thesis, University of Pretoria, Pretoria, South Africa.

DABROWSKI J, OBERHOLSTER PJ, DABROWSKI JM, LE BRASSEUR J and GIESKES J (2013) Chemical characteristics and limnology of Loskop Dam on the Olifants River (South Africa), in light of recent fish and crocodile mortalities. Water SA 39 675-686.

DE VILLIERS S and MKWELO ST (2009) Has monitoring failed the Olifants River, Mpumalanga? Water SA 35 671-676.

DODDS W and WHILES M (2010) Freshwater Ecology. Concepts and Environmental Applications of Limnology ( $2^{\text {nd }}$ edn.). Elsevier, Burlington, USA.

DWAF (DEPARTMENT OF WATER AFFAIRS AND FORESTRY, SOUTH AFRICA) (1996a) South African Water Quality Guidelines. Vol. 7: Aquatic Ecosystems. Department of Water Affairs and Forestry, Pretoria.

DWAF (DEPARTMENT OF WATER AFFAIRS AND FORESTRY, SOUTH AFRICA) (1996b) South African Water Quality Guidelines. Vol. 4: Agricultural Use: Irrigation. Department of Water Affairs and Forestry, Pretoria.

DWAF (DEPARTMENT OF WATER AFFAIRS AND FORESTRY, SOUTH AFRICA) (2002) National Eutrophication Monitoring Programme. Implementation Manual. Compiled by: K Murray, M du Preez and CE van Ginkel. Department of Water Affairs and Forestry, Pretoria.

DWA (Department of Water Affairs) (2011) Green Drop Assessment Results 2010/11. Department of Water Affairs, Pretoria.

DWA (DEPARTMENT OF WATER AFFAIRS, SOUTH AFRICA) (2013) Hydrology. URL: <http://www.dwa.gov.za/sites.aspx> (Accessed 5 June 2013).

FERREIRA S and PIENAAR D (2011) Degradation of the crocodile population in the Olifants River gorge of Kruger National Park, South Africa. Aquat. Conserv: Mar. Freshwater Ecosyst. 21 155-164. 
FYTIANOU A, KOUTINAS AF, SARIDOMICHELAKIS MN and KOUTINAS CK (2006) Blood $\alpha$-Tocopherol, selenium and glutathione peroxidase changes and adipose tissue fatty acid changes in kittens with experimental steatitis (yellow fat disease). Biol. Trace Elem. Res. 112 131-143.

GENSEMER RW and PLAYLE RC (1999) The bioavailability and toxicity of aluminium in aquatic environments. Crit. Rev. Environ. Sci. Technol. 29 315-450.

HELSEL DR and HIRSCH RM (2002) Statistical Methods in Water Resources, Techniques of Water Resources Investigations Book 4, Chapter A3. U.S.Geological Survey. URL: http://pubs.usgs.gov/ twri/twri4a3/\#pdf.

HIRSCH RM, SLACK JR and SMITH RA (1982) Techniques of trend analysis for monthly water quality data. Water Resour. Res. 18 $107-121$.

HUCHZERMEYER KDA, GOVENDER D, PIENAAR D and DEACON AR (2011) Steatitis in wild sharptooth catfish, Clarius gariepinus (Burchell), in the Olifants and lower Letaba Rivers in the Kruger National Park, South Africa. J. Fish Dis. 34 489-498.

JOHNSON MR, ANHAEUSSER CR and THOMAS RJ (eds.) (2006) The Geology of South Africa. Geological Society of South Africa, Johannesburg, and Council for Geoscience, Pretoria, South Africa.

LAKE S (2011) Drought and Aquatic Ecosystems: Effects and Responses. Wiley Blackwell, West Sussex, UK.

LARSEN RE (1983) Steatitis and fat necrosis in captive alligators. J. Am. Vet. Med. Assoc. 183 1202-1204.

LEWIS WM Jr (2002) Causes for the high frequency of nitrogen limitation in tropical lakes. Verh. Internat. Verein. Limnol. 28 210-213.

LOEHR RC (1984) Pollution Control for Agriculture (2 ${ }^{\text {nd }}$ edn.). Academic Press Inc, London.

MAGAGULA TF, VAN KOPPEN B and SALLY H (2006) Water Access and Poverty in the Olifants Basin: A Spatial Analysis of Population Distribution, Poverty Prevalence and Trends. Paper presented at: $7^{\text {th }}$ Waternet/ WARFSA/GWPSA Symposium, 1-3 November 2006, Lilongwe, Malawi.

McKEE TB, DOESKEN NJ and KLEIST J (1993) The relationship of drought frequency and duration to time scales. Eighth Conference on Applied Climatology, American Meteorological Society, 17-23 January 1993, Anaheim, CA. 179-186.

MOOLMAN J, QUIBELL G and HOHLS B (1999) A qualitative (GISbased) model of non-point source areas (modelling suspended sediment in the Olifants River catchment). Institute for Water Quality Studies, Department of Water Affairs and Forestry, Pretoria, South Africa.

MUCINA L and RUTHERFORD MC (2006) The Vegetation of South Africa, Lesotho and Swaziland. Strelitzia 19. South African National Biodiversity Institute (SANBI), Pretoria, South Africa.

NKAMBULE TI, KRAUSE RWM, HAARHOFF J and MAMBA BB (2012) Natural organic matter (NOM) in South African waters: NOM characterisation using combined assessment techniques. Water SA 38 697-706.
OBERHOLSTER PJ, MYBURGH JG, ASHTON PJ and BOTHA A-M (2010) Responses of phytoplankton upon exposure to a mixture of acid mine drainage and high levels of nutrient pollution in Lake Loskop, South Africa. Ecotox. Environ. Saf. 73 326-335.

OBERHOLSTER PJ and BOTHA A-M (2011) Dynamics of phytoplankton and phytobenthos in Lake Loskop (South Africa) and downstream irrigation canals. Fundam. Appl. Limnol. 179 169-178.

OBERHOLSTER PJ, MYBURGH JG, ASHTON PJ, COETZEE JJ and BOTHA A-M (2012) Bioaccumulation of aluminium and iron in the food chain of Lake Loskop, South Africa. Ecotox. Environ. Saf. 75 134-141.

OBERHOLSTER PJ, DABROWSKI J and BOTHA A-M (2013) Using modified multiple phosphorus sensitivity indices for mitigation and management of phosphorus loads on a catchment level. Fundam. Appl. Limnol. 182 1-16.

PORRA RJ, THOMPSON WA and KRIEDEMANN PE (1989) Determination of accurate extinction coefficients and simultaneous equations for assaying chlorophylls $a$ and $b$ extracted with four different solvents: verification of the concentration of chlorophyll standards by atomic absorption spectrometry. Biochim. Biophys. Acta 975 384-394.

QIU S and McCOMB AJ (1995) Planktonic and microbial contributions to phosphorus release from fresh and air-dried sediments. Mar. Freshwater Res. 46 1039-1045.

ROBERTS RJ and AGIUS C (2008) Pansteatitis in farmed northern bluefin tuna, Thunnus thynnus (L.), in the eastern Adriatic. J. Fish Dis. 31 83-88.

STEVENS MR (2003) Water quality and trend analysis of Colorado - Big Thompson System reservoirs and related conveyances, 1969 through 2000. U.S. Geological Survey, Water Resources Investigations Report 03-4044.

TIMMS B (2010) Geomorphology of Lake Basins. In: Likens GE (ed.) Lake Ecosystem Ecology. Academic Press San Diego, USA. 203 pp.

TOERIEN DF, HYMAN KL and BRUWER MJ (1975) A preliminary trophic status classification system of some South African impoundments. Water SA 1 15-23.

VAN GINKEL CE (2011) Eutrophication: Present reality and future challenges for South Africa. Water SA 37 693-702.

VAN KOPPEN B (2008) Redressing inequities of the past from a historical perspective: The case of the Olifants basin, South Africa. Water SA 34 432-438.

VOLLENWEIDER RE (1968) Scientific fundamentals of the eutrophication of lakes and flowing waters, with particular reference to nitrogen and phosphorus as factors in eutrophication. OECD Technical Report DA 5/SCI/68.27, Paris, France.

WALMSLEY RD and BUTTY M (1980) The Limnology of Some Selected South African Impoundments. National Institute for Water Research, CSIR, Pretoria.

SVOBODA M, HAYES M and WOOD D (2012) Standardised Precipitation Index User Guide. WMO-No. 1090. World Meteorological Organisation, Geneva.

WETZEL RG (1983) Limnology (2 ${ }^{\text {nd }}$ edn.) Saunders College Publishing, Orlando, USA 
http://dx.doi.org/10.4314/wsa.v40i2.17 Available on website http://www.wrc.org.za

ISSN 0378-4738 (Print) $=$ Water SA Vol. 40 No. 2 April 2014 ISSN 1816-7950 (On-line) = Water SA Vol. 40 No. 2 April 2014 